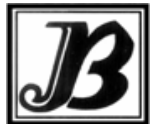

J. bio-sci. 20: 1-23, 2012

ISSN 1023-8654

http://www.banglajol.info/index.php/JBS/index

\title{
INTRACELLULAR SIGNALING BY BILE ACIDS
}

- Review Article

\author{
Mohammed Sawkat Anwer* \\ Department of Biomedical Sciences \\ Cummings School of Veterinary Medicine at Tufts University \\ 200 Westboro Road, North Grafton, MA, USA
}

\begin{abstract}
Bile acids, synthesized from cholesterol, are known to produce beneficial as well as toxic effects in the liver. The beneficial effects include choleresis, immunomodulation, cell survival, while the toxic effects include cholestasis, apoptosis and cellular toxicity. It is believed that bile acids produce many of these effects by activating intracellular signaling pathways. However, it has been a challenge to relate intracellular signaling to specific and at times opposing effects of bile acids. It is becoming evident that bile acids produce different effects by activating different isoforms of phosphoinositide 3-kinase (PI3K), Protein kinase Cs (PKCs), and mitogen activated protein kinases (MAPK). Thus, the apoptotic effect of bile acids may be mediated via PI3K-110 $\gamma$, while cytoprotection induce by CAMP-GEF pathway involves activation of PI3K-p110 $\alpha / \beta$ isoforms. Atypical PKC $\zeta$ may mediate beneficial effects and $\mathrm{nPKC} \varepsilon$ may mediate toxic effects, while $\mathrm{CPKC} \alpha$ and $\mathrm{nPKC} \delta$ may be involved in both beneficial and toxic effects of bile acids. The opposing effects of $\mathrm{nPKC} \delta$ activation may depend on $\mathrm{nPKC} \delta$ phosphorylation site(s). Activation of ERK1/2 and JNK1/2 pathway appears to mediate beneficial and toxic effects, respectively,of bile acids. Activation of $p 38 \alpha$ MAPK and p38 $\beta$ MAPK may mediate choleretic and cholestatic effects, respectively, of bile acids. Future studies clarifying the isoform specific effects on bile formation should allow us to define potential therapeutic targets in the treatment of cholestatic disorders.
\end{abstract}

Key words: PI3K, PKC, MAPK, Bile formation, Cholestasis.

\section{Introduction}

Bile acids were shown to play an important role in bile formation by the liver as early as 1870 (Schiff, 1870). Since then bile acids have been shown to produce diverse cellular effects, that can be beneficial as well detrimental to cells(Maillette de Buy and Beuers, 2010). The beneficial effects include stimulation of bile formation, immunomodulation, cell survival, while the toxic effects include inhibition of bile formation, apoptosis and cellular toxicity. It is becoming evident that bile acids produce many of these effects by activating intracellular signaling pathways, including CAMP, calcium, phosphoinositide 3-kinase (PI3K), Protein kinase Cs (PKCs), mitogen activated protein kinases (MAPK) and others (Amaya and Nathanson 2013, Anwer 2004, Hylemon et al. 2009, Maillette de Buy and Beuers 2010, Nguyen and Bouscarel 2008).

Activation of signaling pathways may, in some cases, involve activation of cell surface receptors, such as TGR5 (Pols et al. 2011) and spingosine-1-phosphate receptor2 (Studer et al. 2012) by bile acids. Interestingly, the same signaling pathways can be activated by bile acids producing opposing effects. Thus, it has been a challenge to relate intracellular signaling to specific and at times opposing effects of bile acids.

* Corresponding address: Telephone number: 508-839-8788, Fax number: 508-839-8787. Email: sawkat.anwer@tufts.edu 
Studies in recent years have provided a better understanding of the mechanisms underlying toxic versus beneficial effects of bile acids. This review focuses on the signaling pathways postulated to be involved in bile acid mediated bile formation and cholestasis.

\section{Bile formation and cholestasis}

The liver, the largest gland in the body, plays a central role in the metabolism and excretion of endogenous and exogenous solutes (Anwer 1991, Anwer 2004, Nathanson and Boyer 1991). Bile is the exocrine secretion of the liver. The site of initial bile formation is the canalicular space between two hepatocytes. Thus, bile formed by hepatocytes are known as canalicular bile as opposed to ductularbile formed by bile ductular cells. Canalicular bile is modified by ductular cells before being stored in the gall bladder for animals with gallbladder. Animals without gall bladder appear to store bile in the bile duct. Bile can be further modified (i.e., concentrated) in gall bladder. Following a meal bile from the gall bladder is emptied into the duodenum. Bile provides a route of excretion for many endogenous and exogenous solutes. Bile also assists in digestion and absorption of fat by providing bile acids and phospholipids to the duodenum and plays an immunological role by delivering IgA to the intestine.

Bile being an aqueous solution ( $97.5 \%$ water) is more suitable for the excretion of water soluble compounds. However, the presence of micelle forming bile acids above their critical micellar concentration allows solubilization of lipids in bile. Thus, water-soluble as well as lipid-soluble compounds are excreted via the biliary route. Only solutes that are excreted into the bile directly contribute to bile formation and these solutes include like bile acids, cholesterol, phospholipid, bilirubin, proteins, inorganic ions, glutathione, drugs and toxins. Since biliary solutes are, in most part, derived from sinusoidal blood, vectorial transport of solutes from the sinusoidal space to the canaliculus provides the osmotic driving force for bile formation and is accomplished by various transporters located at the basolateral and canalicular membrane of hepatocytes and cholangiocytes(Anwer 1993, Anwer 1998, Hagenbuch and Meier 2003, Kanno et al. 2001,Mennone et al. 2001, Singh et al. 2001,Trauner and Boyer 2003).

Agents that increase bile formation are known as choleretic agents, while agents that decrease bile formation are known as cholestatic agents. Bile acids have been shown to produce choleresis as well as cholestasis (Anwer 2004,Maillette de Buy and Beuers 2010).The term "cholestasis" is used to describe conditions associated with decreased bile formation. It is thus easy to appreciate the paradigm that cholestasis results when the ability of the liver to transport solutes into the canaliculus is compromised.

Our present understanding of the pathogenesis of cholestasis is based on studies to define the physiological regulation of various transporters involved in bile formation (Fig. 1) and their deregulation in experimental models of cholestasis and patients with cholestatic disorders (Bohan and Boyer 2002, Elferink and Groen 2002, Jansen et al. 2001, Lee and Boyer 2000). In addition, studies on the expression of transporters in cholestatic diseases have provided valuable information on the role of specific transporters in the pathogenesis of some of these diseases. It is becoming clear that bile acids produce acute choleresis or cholestasis by altering signaling pathways that regulate hepatobiliary solute transporters. 


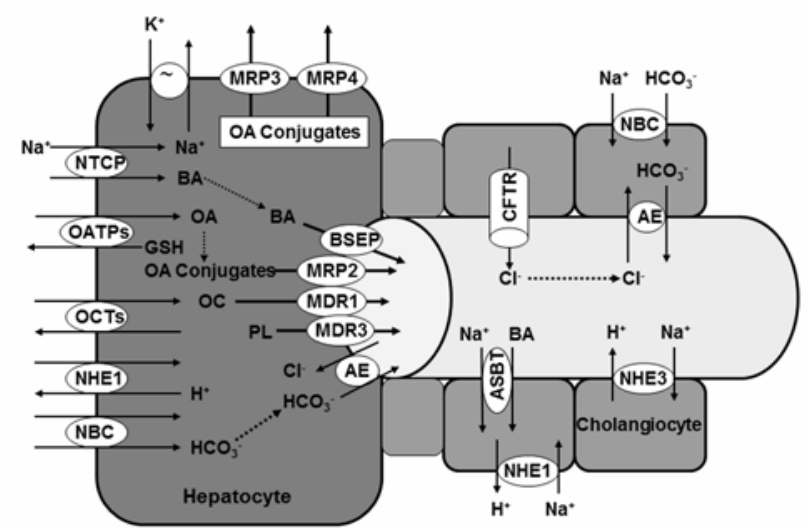

Fig.1. Transporters involved in bile formation: hepatic uptake of bile acid (BA), organic anions (OA) and organic cations $(\mathrm{OC})$ is mediated primarily by $\mathrm{Na}^{+} /$taurocholate cotransporting polypeptide (NTCP), the family of organic anion transporting proteins (OATPs) and organic cation transporters (OCTs), respectively. $\mathrm{Na}^{+} / \mathrm{H}^{+}$exchanger (NHE1) and $\mathrm{Na}^{+} / \mathrm{HCO}_{3}$-cotransporter (NBC) at the sinusoidal membrane of hepatocytes and basolateral membrane of cholangiocytes are involved in intracellular $\mathrm{pH}$ regulation and $\mathrm{HCO}_{3}{ }^{-}$excretion. $\mathrm{NHE} 3$ present on the apical membrane is involved in fluid absorption, and $\mathrm{Na}^{+}-\mathrm{K}^{+}-2 \mathrm{Cl}^{-}$(not shown) may be involved in fluid secretion in cholagiocytes. Multi-drug resistance proteins (MRP3 and MRP4) mediate sinusoidal efflux of organic anions, including toxic bile acids, while MRP2 and BSEP (Bile salt export pump) mediate canalicular excretion of conjugated organic anions and bile acids, respectively. MDR1 and MDR2 (multidrug resistance gene products) are involved in biliary excretion of organic cations and phospholipids, respectively. Chloride/bicarbonate exchange is mediated by anion exchanger (AE) at canalicular as well as apical membrane of cholangiocytes. Cystic fibrosis transmembrane conductance regulators (CFTR) act as chloride channels and reabsoprtion of conjugated bile acid from the biliary tree is mediated via the apical $\mathrm{Na}^{+}$-dependent bile acid transporter (ASBT).

\section{Bile acids}

Bile acids are steroid acids synthesized from cholesterol in the liver. Bile acids undergo extensive enterohepatic circulation (Hofmann 2009, Hofmann and Hagey 2008), which involves cycling of bile acids from the liver to the intestine via bile duct and from intestine to the liver via the portal vein. The first and the rate limiting step of bile acid synthesis is the hydroxylation of cholesterol by cholesterol 7-a-hydrozylase (CYP7A1). Bile acids synthesized in the liver, such as cholic acid (CA; $3 \alpha, 7 \alpha, 12 \alpha$-trihydroxycholanic acid) and chenodeoxycholic acid (CDCA; $3 \alpha, 7 \alpha$-dihydroxycholanic acid) are termed primary bile acids. Cholic and chenoxeodycholic acids are dehydroxylated to secondary bile acids,deoxycholic acid (DCA; $3 \alpha, 12 \alpha-$ dihydroxycholanic acid) and lithocholic acid (LCA; $3 \alpha$-monohydroxycholanic acid), respectively, by intestinal bacteria (Fig. 2). In addition, ursodexoycholic acid (UDCA; $3 \alpha, 7 \beta$-dihydroxycholanic acid), a primary bile acid in bears, nutria and beavers,can be synthesized to a limited extent from chenodeoxycholic acid by epimerization in the liver of other species(Hofmann 2009). All bile acids can be conjugated with either taurine or glycine in the liver to form tauro-bile acids and glycol-bile acids, respectively. These conjugated bile acids are stronger acids (Hofmann and Hagey, 2008)and hence less permeable than their respective unconjugated bile acids; conjugated bile acids are deconjugated by bacterial enzymes in the intestine. The enterohepaticcirculation of bile acids (Fig. 3) are maintained by various transporters present in the liver and the intestine (Kosters and Karpen 2008). 


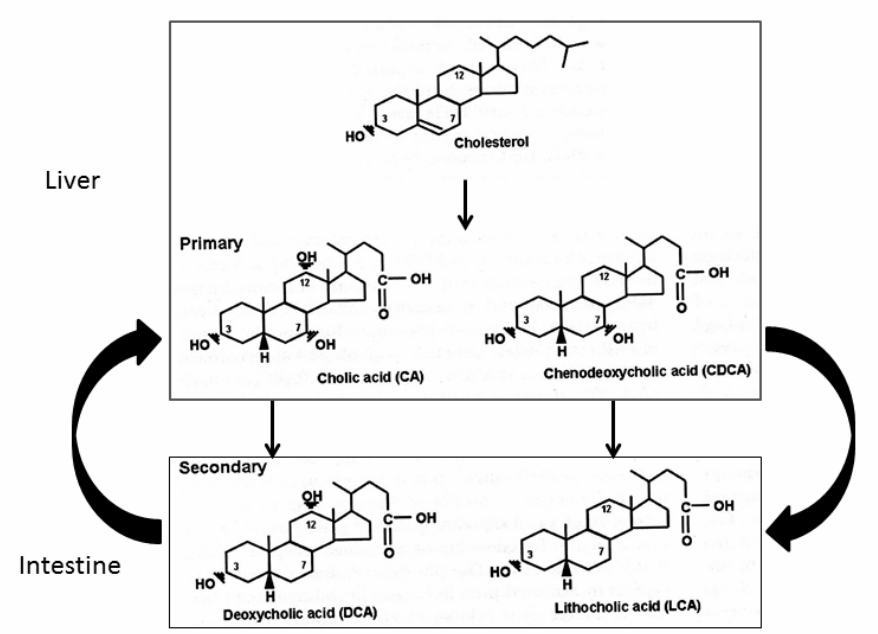

Fig.2. Primary bile acids (CA and $C D C A)$ are synthesized from cholesterol in the liver and are converted to secondary bile acids (DCA and TCA) in the intestine. Secondary bile acids are absorbed from the intestine and taken up and secreted by the liver. Thus, bile contains primary as well as secondary bile acids (Hofmann 2009).

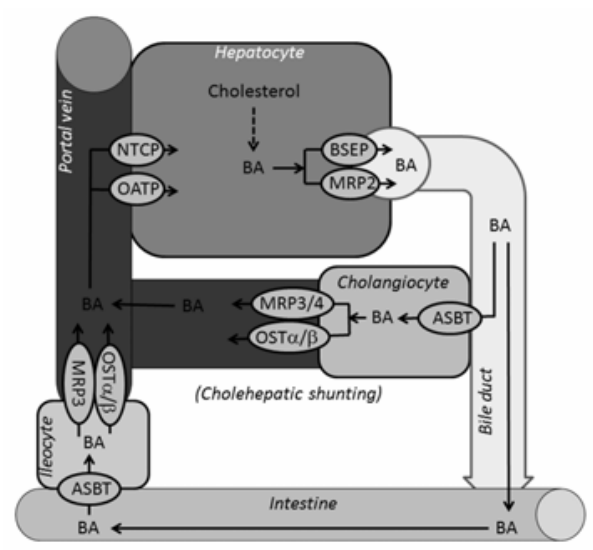

Fig.3. Enterohepatic circulation of bile acids. Bile acids are active secreted into bile canaliculi by bile acid export pump (BSEP) and multidrug associated protein 2 (MRP2). Secreted bile acids flow down the biliary tract to the gallbladder for storage and then delivered to the upper intestine following meal. During the passage through the bile duct, a small fraction of BA undergoes reabsorption through cholangiocytes into the portal blood by transporters located at the luminal side (ASBT) and basolateral side (MRP3/4 and OST $\alpha / \beta)$ and then into the hepatocytes. This cycling of bile acids between cholangiocytes and hepatocytes is known as cholehepatic shunting. In the intestine, bile acids are absorbed across ileocytes into the portal blood by ASBT at the luminal side and MRP3 and OST $\alpha / \beta$ on the basolateral side. Bile acids in the portal blood are transported at a high efficiency into hepatocytes by sodium-dependent NTCP as well as sodium-independent OATP1B1 and OATP1B3 present at the sinusoidal membrane of hepatocytes. BSEP = Bile acid export pump, MRP = multidrug resistance-associated protein, $A S B T=$ apical sodium-dependent bile acid transporter , OST $=$ organic solute transporter, NTCAP = sodium/taurocholate co-transporting polypeptide, OATP = organic anion transporting polypeptide. 
Physicochemical properties \& biological effects of bile acids: Bile acids, because of their beneficial as well as toxic effects, can be divided into three board groups: Bile acids that have a) beneficial effects, b) beneficial and toxic effects and $c$ ) toxic effects. The corresponding bile acids are sometimes termed the good (CA, UDCA), the bad (CDCA, DCA) and the ugly bile acids (LCA), respectively (Hofmann 1999). Bile acids are planar molecules with a hydrophobic (steroid backbone) and a hydrophilic side (hydroxyl groups). With the exception of UDCA, the hydrophobicity of a bile acid increases with decreasing hydroxyl groups. UDCA is less hydrophobic than CDCA because of beta orientation of the 7-hydroxyl group. This spatial orientation allows the bile acids to solubilize lipids by forming micelle.lt is of note that the beneficial effects are observed with bile acids that are more hydrophilic, while the toxic effects are seen with bile acids that are more hydrophobic. More specifically, CA and UDCA produce beneficial effects, while LCA produces toxic effects. Thus, taurine conjugates of these bile acids (TCA, TUDCA and TLCA) have often been used to study the mechanism of bile acids induced choleresis and cholestasis.

\section{Signaling pathways affected by bile acids}

For a long time bile acids have been considered to be detergent molecules (also termed biological soap) involved in the solubilization of cholesterol in bile and digestion of fat in the intestine. The ability of bile acids to produce choleresis is due to osmotic force generated by active secretion of bile acids and other solutes into the bile canaliculus. Over the last two decades, this passive role of bile acids has been replaced by a more active role as regulatory/signaling molecules. Bile acids have been shown to affect a variety of signaling pathways involved in the regulation of various cellular activities. These effects are best exemplified by choleretic/cholestatic and apoptotic/antiapoptotic effects of bile acids. Thus, GCDCA and TCDCA, which predominantly accumulate in patients with cholestatic diseases, have been shown to produce apoptosis and cholestasis in experimental models (Perez and Briz 2009, Rust et al. 2005). In contrast, more hydrophilic bile salts, such as TUDCA and TCA, promote cell survival, produce choleresis, and reestablish normal liver function in cholestasis (Amaral et al. 2009, Paumgartner and Beuers 2004, Perez and Briz 2009). Despite these opposing effects, these bile acids have been shown to activate the same intracellular signaling kinases, such as PI3K, PKCs and MAPKs. What is emerging as a theme is that bile acids produce different and at time opposing effects by activating different isoforms of PI3K, PKC and MAPK, as described below.

\section{III a . Role of PI3K pathway}

PI3Ks are a family of lipid kinases (classes I, II, and III) that phosphorylate the inositol ring of phosphatidylinositides (PIs)at 3 position known as D3 phosphorylation(Cantley, 2002). The resulting phosphorylated PIs (PIPs), acting in concert with phosphoinositide-dependent kinases (PDKs), are involved in the activation of downstream kinases, such as PKC $/ \lambda$, Akt/PKB, and p70s6k. These kinases are involved in vesicle trafficking, cell survival, cell proliferations, cell migration, and transport of glucose and bile acids. (Anwer 1998, Rameh and Cantley 1999, Toker 2000).Among the various classes of PI3K, the class IA PI3K is primarily responsible for production of D-3 phosphoinositides in response to growth factors (Cantley 2002). The Class IA PI3K consists of a regulatory subunit, $\mathrm{p} 85$, and one of the three catalytic $\mathrm{p} 110$ subunits $(\mathrm{p} 110 \alpha / \mathrm{p} 110 \beta / \mathrm{p} 110 \delta)$. The catalytic subunit is mainly activated by binding of $p 85$ to a phosphotyrosyl peptide in tyrosine kinases (Cantley 2002). Moreover, it has been shown that p110 $\beta$ can also be activated by $G$ protein-coupled receptors (Guillermet-Guibert et al. 2008). The Class IB PI3K has a single catalytic isoform, $p 110 \gamma$, which interacts with the regulatory subunit $p 101$, and is activated by $\beta / \gamma$ subunits of $\mathrm{G}$ proteins (Cantley 2002). The in vivo substrate for Class I PI3Ks is PI-4, 5-diphosphate (PI-4,5-P2), which is converted to the signaling molecule PI-3,4,5-P3 (PIP3). PIP3 serves as a docking site for the binding and activation of downstream signaling molecules, including Akt (Cantley 2002).

It is becoming evident that different PI3K p110 isoforms mediate different cellular events. For example, activation ofp110 ais implicated in cell survival (Benistant et al. 2000, Gates et al. 2009), physiologic cardiac hypertrophy (Pretorius et al. 2009), and insulin signaling (Foukas et al. 2006). De novo DNA synthesis (Benistant et al. 2000) 
and carcinogenesis (Jia et al. 2008) are associated with activation of p110ß. In contrast, the induction of inflammatory responses by $\mathrm{p} 110 \delta$ is primarily confined to the hemopoietic system. Although $\mathrm{p} 110 \gamma$ was long believed to be restricted to immunecells (Hawkins and Stephens 2007), recent studies suggest a role for p110yin the development of atherosclerotic lesions (Chang et al. 2007), loss of cardiac contractility (Pretorius et al. 2009), andacute pancreatitis (Fischer et al. 2007, Lupia et al. 2004). Thus, p110 $\alpha$ appears to mediate beneficial effects, while $110 \gamma$ may mediate toxic effects. Studies in hepatic cells suggest that the opposing effects of bile acids may also be mediated via different isoforms of class I PI3K.

A role of PI3K in bile formation is evident from a study (Folli et al. 1997) showing that wortmannin, a specific inhibitor of PI3K, inhibits bile formation, bile acid secretion and vesicle trafficking in isolated perfused rat liver. Since then various studies have provided evidence supporting a role for PI3K/Akt pathway in cell survival and translocation of hepatocellular transporters to the plasma membrane, indicating a beneficial role of PI3K in hepatic cells (Anwer 2004, Gates et al. 2009, Rust et al. 2005 ,Webster et al. 2002b). However, it is now evident that choleretic (TCA and TUDCA) as well as cholestatic (TLCA and TCDCA) bile acids activate PI3K (Beuers et al. 2003, Kurz et al. 2000, Misra et al. 1998, Rust et al. 2000). Thus, it would appear that PI3K may mediate beneficial as well as toxic effects of bile acids. In that case, the opposing effects of bile acids may be mediated via different $\mathrm{PI} 3 \mathrm{~K} / \mathrm{p} 110$ isoforms. Indeed studies in rat hepatocytes with choleretic (TUDCA and TCA) and cholestatic (TCDCA, GCDCA, TLCA) bile acids showed that all bile acids activated PI3K-p110 $\beta$, but only toxic bile acids activated PI3Kp110y (Hohenester et al. 2010). Further studies showed that inhibition of p110y attenuated GCDCA-induced apoptosis and activation of c-Jun N-terminal kinase (JNK), but did not alter TUDCA- or CAMP-induced Akt-signaling (Hohenester et al. 2010).Since activation p110y is associated with toxic effects in non-hepatic cells (Chang et al. 2007, Fischer et al. 2007, Lupia et al. 2004, Pretorius et al. 2009), these results in hepatocytes would suggest that the toxic effect of bile acids may be mediated by activation of PI3K-p110y pathway. Moreover, since Activation of JNK pathway has been linked to bile acid-induced hepatotoxicity (Graf et al. 2002a, Gupta et al. 2004a, Usechak et al. 2008) and PI3K-p110y has been shown to induce JNK-mediated signaling cascades in non-hepatic cells (Go et al. 1998), the cytotoxic effect of bile acids may be mediated via PI3K-p110 $\gamma$-JNK pathway. On the other hand, the beneficial effects of bile acids may be mediated via PI3K-p110 $\alpha / \beta$-Akt pathway (Fig. 4).

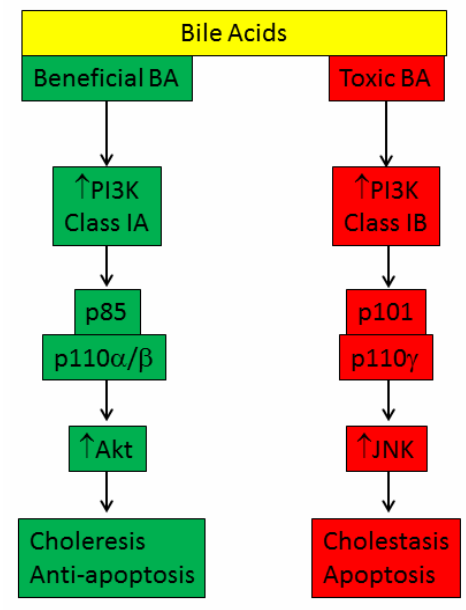

Fig.4. Postulated role of PI3K-p110 isoforms in beneficial and toxic effects of bile acids. Beneficial effects (choleresis and anti-apoptosis) of bile acids are mediated via PI3K/p110 $\alpha / \beta /$ Akt pathway, while the toxic effects (cholestasis and apoptosis) is mediated via $\mathrm{PI} 3 \mathrm{~K} / \mathrm{p} 110 \gamma / \mathrm{JNK}$ pathway 
Such a hypothesis is consistent with the other findings that a) PI3K-Akt pathway is cytoprotective(Gates et al. 2009, Rust et al. 2005, Webster et al. 2002b), b) the cytoprotectiveeffect of CAMP-GEF in hepatocytes is associated with PI3Kp110 $\alpha / \mathrm{p} 110 \beta$ activation (Gates et al. 2009), and c) PI3K-p110 $\alpha$ is necessaryfor insulin signaling in the liver(Foukas et al. 2006).

\section{Illb. Role of Protein kinase C}

Protein kinase $\mathrm{C}$ belongs to a family of serine/threonine protein kinases that are involved in the regulation of diverse cellular functions andconsists of at least 12 isoforms (Newton 2003, Reyland 2009). These include conventional ( $\mathrm{cPKC} \alpha, \beta, \beta \mathrm{l}, \beta \|$ and $\gamma$ ), novel (nPKC $\delta, \varepsilon, \eta$ and $\theta$ ), atypical (aPKC $\zeta$ and $\lambda / \mathrm{t}$ ) isoforms . These isoforms differ in their dependency on $\mathrm{Ca}^{2+}$ and phospholipids, such that $\mathrm{CPKC}$ are dependent on $\mathrm{Ca}^{2+}$ and diacylglycerol (DAG), nPKCs are $\mathrm{Ca}^{2+}$-independent and $\mathrm{aPKC}$ s are independent of both $\mathrm{Ca}^{2+}$ and DAG (Fig. 5).Activation of most PKCs, if not all, is PI3K dependent (Newton 2003).PKCs shown to be present in rat hepatocytes include $\mathrm{CPKC} \alpha, \mathrm{nPKC} \delta, \mathrm{nPKC} \varepsilon$, and $\mathrm{aPKC} \zeta$ with the presence of $\mathrm{CPKC} \beta \|$ being controversial. (Beuers et al. 1999, Jones et al. 1997, Stravitz et al. 1996).

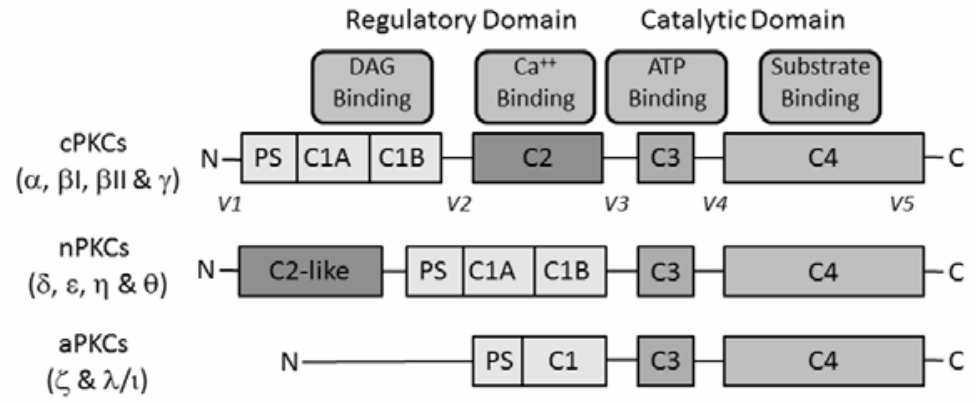

Fig.5. Primary structures of PKCs(Michalczyk et al. 2013,Newton 2003, Newton 2010, Reyland 2009, Tan and Parker 2003). There are four structurally conserved domains (C1-C4) in PKC isoforms divided into the N-terminal regulatory domain (C1-C2) and the C-terminal catalytic domain (C2-C4). The regulatory domain contain the binding sites for pseudosubstrate (PS), DAG (C1) and $\mathrm{Ca}^{++}$(C2 or C2-like). The catalytic domain contains the binding sites of ATP (C3) and substrate (C4). C-regions (C1-C4) represent conserved domains and V-regions represent variable domains (V1-V5). The regulatory and the catalytic domains are separated by a flexible hinge domain (V3), which is cleaved by caspase-3 in apoptotic cells. Novel isozymes contain a C2-like domain which is unable to bind $\mathrm{Ca}^{++}$and hence do not require $\mathrm{Ca}^{++}$for activation. Atypical isozymes contain a variant of the $\mathrm{C} 1$ domain, which lacks the ligand-binding pocket for DAG and lacks $\mathrm{C} 2$ domain. As a result aPKCs are not regulated by DAG and $\mathrm{Ca}^{++}$; they are regulated by protein-protein interactions. The intermolecular binding between PS and catalytic domain is highly regulated by membrane interactions, PKC conformation and phosphorylation.

Initial studies using known general activators and inhibitors of conventional and novel PKCs suggested that activation of PKCs produce cholestasis (Anwer 2004). However, both choleretic and cholestatic bile acids activate PKCs (Table 1) and PKCs have now been implicated in apoptotic, anti-apoptotic, cholestatic and choleretic effects of bile acids and other agents, (Anwer 2004, Castello et al. 2005, Jones et al. 1997, Kubitz et al. 2004a, Paumgartner and Beuers 2004, Perez et al. 2006, Rust et al. 2000).It is becoming evident that the opposing effects of bile acids may be mediated via different isoforms of PKCs, although the role of all PKC isoforms has not been clearly established. Studies to date would indicate that aPKC $\zeta$ may mediate beneficial effects and $\mathrm{nPKC} \varepsilon$ may mediate toxic effects, while $\mathrm{cPKC} \alpha$ and $\mathrm{nPKC} \delta$ may be involved in both beneficial and toxic effects of bile acids. 
Table 1.Effect of bile acids on PKC isoforms and the reported role of PKC isoforms in hepatic cells.

\begin{tabular}{|c|c|c|c|c|c|c|c|}
\hline $\begin{array}{l}\text { PKC } \\
\text { isoforms }\end{array}$ & TCA & TUDCA & GCDCA & TCDCA & TDCA & TLCA & Role of PKC isoforms \\
\hline $\mathrm{cPKC} \alpha$ & $\uparrow /-$ & $\uparrow$ & $\uparrow$ & $\uparrow$ & $\uparrow$ & $\downarrow$ & $\begin{array}{l}\text { Cholestasis (Kubitz et al. 2004a) } \\
\text { Apoptosis (Jones et al. 1997), } \\
\text { anticholestatic (Wimmer et al. } \\
\text { 2008), Ntcp retrieval (Muhlfeld et } \\
\text { al. 2012), Mrp2 translocation } \\
\text { (Beuers et al. 2001) } \\
\text { Apoptosis (Jones et al. 1997), }\end{array}$ \\
\hline $\mathrm{nPKC} \delta$ & $\uparrow /-$ & - & $\uparrow$ & $\uparrow$ & $\uparrow$ & - & $\begin{array}{l}\text { Non-bile acid cytotoxicity } \\
\text { (Castello et al. 2005, Maddox } \\
\text { et al. 2003), Ntcp \& Mrp2 } \\
\text { translocation (Park et al. 2012, } \\
\text { Schonhoff et al. 2008), } \\
\text { Antiapoptotic (unpublished) } \\
\text { Cholestasis (Beuers et al. }\end{array}$ \\
\hline $\mathrm{nPKC} \varepsilon$ & $\uparrow /-$ & - & $\uparrow$ & ND & ND & $\uparrow$ & $\begin{array}{l}\text { 2003),Mrp2 retrieval (Schonhoff } \\
\text { et al. 2013) }\end{array}$ \\
\hline aPKC $\zeta$ & - & ND & ND & $\uparrow$ & ND & - & $\begin{array}{l}\text { Ntcp translocation (McConkey et } \\
\text { al. 2004), Antiapoptosis (Rust et } \\
\text { al. 2000), Activation of insulin } \\
\text { signaling pathway (Cao et al. } \\
\text { 2010) }\end{array}$ \\
\hline
\end{tabular}

TCA (Beuers et al. 1996, Rao et al. 1997, Stravitz et al. 1996), TUDCA (Beuers et al. 1996, Rao et al. 1997), GCDCA(Jones et al. 1997), TCDCA(Lali et al. 2000, Rao et al. 1997), TDCA (Rao et al. 1997) and TLCA (Beuers et al. 2001, Beuers et al. 2003, Schonhoff et al. 2013) has been shown to affect PKC isoforms activity in hepatocytes. TCA has been reported to activate (Rao et al. 1997, Stravitz et al. 1996) or have no effect on CPKC $\alpha$ (Beuers et al. 1996) in hepatocytes. The effect of TCA is dependent on PKC (Cao et al. 2010), but TCA has not been reported to activate PKC $\zeta$. Activation $(\uparrow)$, inhibition $(\downarrow)$ or no effect $(-)$; ND= not determined.

Role of $\mathrm{cPKC} / \mathrm{CPKC} \alpha$ : Activation of $\mathrm{CPKC} \alpha$ has been implicated in cardiomyocyte hypertrophy, thrombus formation, cell proliferation and apoptosis in non-hepatic cells (Konopatskaya and Poole 2010, Reyland 2009).Both choleretic and cholestatic bile acids can activate $\mathrm{cPKC} \alpha$ (Table 1) and $\mathrm{CPKC} \alpha$ has been suggested to mediate bile acid-induced beneficial as well as toxic effects.

TUDCA activatesc PKC $\alpha$ in isolated rat hepatocytes(Beuers et al. 1996)and CPKC $\alpha$ may be involved in the translocation of Mrp2 to the canalicular membrane by TUDCA (Beuers et al. 2001). TUDCA has been shown to reverse TLCA-induced cholestasis(Beuers et al. 2001, Scholmerich et al. 1990)and it has been suggested that TUDCA may reverse TLCA-induced cholestasis by activating cPKC $\alpha$ (Beuers et al. 2001, Beuers et al. 1996). This is consistent with a recent study showing that TUDCA-induced reversal of TLCA-mediated decreases in bile formation is partially inhibited by combined inhibition of CPKC and PKA (Wimmer et al. 2008). Interestingly, inhibition of CPKC or PKA alone did not reverse TUDCA effect. Also, neither TUDCA nor TLCA affected PKA activity in hepatocytes. It is suggested that the anticholestatic effect of TUDCA may in part be mediated via cooperative post-translational $\mathrm{CPKC} \alpha$-/PKA-dependent mechanisms. The nature of this postulated cooperative mechanism remains to be evaluated. It may be noted that acute cholestasis induced by TLCA and ethinylestradiol17ßglucuronide is associated with retrieval of Bsep and Mrp2 from the canalicular membrane and these effects are reversed by cAMP (Crocenzi et al. 2003a, Crocenzi et al. 2003b, Mottino et al. 2002).It is however not known whether the anticholestaticeffect of CAMP, which does not activate $\mathrm{CPKC} \alpha$ in hepatocytes (Schonhoff et al. 2008), may also require a permissive role of $\mathrm{CPKC} \alpha$. 
In contrast, $\mathrm{CPKC} \alpha$ has also been implicated in effects of bile acids that are not beneficial. For example, GCDCAinduced apoptosis requires activation of $\mathrm{CPKC} \alpha$ (Jones et al. 1997) and CPKCs have been reported to mediate cholestasis induced by drug and oxidative stress (Kubitz et al. 2004a, Perez et al. 2006). In addition, a recent study showed that activation of CPKC by TCDCA, a cholestatic bile acid, or thymeleatoxin can lead to retrieval of Ntcp from the plasma membrane and thereby decrease bile acid uptake (Muhlfeld et al. 2012, Stross et al. 2010). Conventional PKCs have also been implicated in cholestasis associated with Bsep retrieval (Kubitz et al. 2004a, Perez et al. 2006). On the other hand, TLCA induces retrieval of Ntcp in rat hepatocytes (Schonhoff et al. 2009), but inhibits $\mathrm{CPKCa}$ (Beuers et al. 2001). Thus, the retrieval of Ntcp by bile acids may involve mediators in addition to CPKC $\alpha$.

These studies suggest that $\mathrm{CPKC} \alpha$ may mediate cholestasis as well as anticholestatic effects of bile acids. The mechanism by which this is accomplished is unclear at this time. It is possible that activation of $\mathrm{CPKC} \alpha$ by choleretic and cholestatic bile acids involves translocation to different subcellular membrane resulting in activation/inhibition of different downstream effectors. In that case, the opposing effects of $\mathrm{CPKC} \alpha$ may be dependent on downstream effectors affected. Thus, it would be useful to know if $\mathrm{CPKC} \alpha$ is targeted to different cellular sites by choleretic and cholestatic bile acids. It may be noted that the role of cPKC $\alpha$ in these studies were evaluated by using chemical inhibitors, which may not be as specific as currently believed. Further studies using other approaches (knockout, knockdown, constitutively active and dominant negative mutants) to activate and inhibit cPKC $\alpha$ are needed to establish the role of cPKCa.

Role of PKC 8 : While certain bile acids have been shown to activate $n P K C \delta$ (Table 1), only limited studies have evaluated the role of $\mathrm{nPKC} \delta$ in the effects of bile acids. One study using chemical inhibitors of PKCs suggested that GCDCA-induced apoptosis in hepatocytes requires activation of $n$ PKC $\delta$ (Jones et al. 1997). However, a recent study using molecular activators and inhibitors of $n P K C \delta$ showed that activation of $\mathrm{nPKC} \delta$ by GCDCA actually induces a cytoprotective pathway by inhibiting JNK activation and down-regulating proapototic BIM (unpublished data). Other studies suggest that $\mathrm{nPKC} \delta$ may be involved in allyl alcohol-induced hepatotoxicity (Maddox et al. 2003) and 4-hydroxynonenal-induced apoptosis in hepatocytes (Castello et al. 2005). In contrast, cAMP, a known choleretic and anti-apoptotic agent (Webster et al. 2002b, Webster and Anwer 1998), activates nPKC $\delta$ and nPKC $\delta$ has also been shown to mediate CAMP-induced translocation of NTCP and MRP2 to the plasma membrane (Park et al. 2012, Schonhoff et al. 2008). This is consistent with known transporter regulatory effect of $\mathrm{nPKC} \delta$, which include stimulation of $\mathrm{Na}^{+}-\mathrm{H}^{+}$exchanger in glial cells (Chen and Wu 1995), a1-adrenergic activation of $\mathrm{Na}^{+}-\mathrm{K}^{+}-2 \mathrm{Cl}$ cotransport in tracheal epithelial cells (Liedtke and Cole 1997), insulin-mediated GLUT4 translocation in myocytes and adipocytes (Braiman et al. 1999, Elmendorf 2002) and serotonin-mediated inhibition of $\mathrm{Cl} / \mathrm{OH}$ - exchange in Caco-2 cells (Saksena et al. 2005). Thus, it appears that nPKC $\delta$ may mediate both toxic and beneficial effects in hepatocytes. The mechanism by which this is accomplished is unclear and may be related to phosphorylation of nPKC $\delta$.

Novel PKC $\delta$ has been reported to positively and negatively regulate apoptosis depending on sites phosphorylated by various stimuli (Brodie and Blumberg 2003, Jackson and Foster 2004). It has been suggested that the cleavage of activated $\mathrm{nPKC} \delta$ to a catalytic fragment stimulates apoptosis (Jackson and Foster 2004). The cleavage of nPKC $\delta$ appears to be dependent on phosphorylation at Tyr ${ }^{311}$ (Yoshida 2007) and the phosphorylation at this site by c-Abl, a nonreceptor tyrosine kinase, promotes the apoptotic effect of $\mathrm{nPKC} \delta$ in glioma cells (Lu et al. 2007). Tyrosine phosphorylated $\mathrm{nPKC} \delta$ transiently accumulates in the nucleus, where it is cleaved by caspase- 3 to generate the $\mathrm{nPKC} \delta$ catalytic fragment (delta-CF), a constitutively activated, pro-apoptotic form of $\mathrm{nPKC} \delta$ (Reyland 2009). On the other hand, the PI3K-dependent activation of nPKC $\delta$ by serum in HEK293 cells (Le Good et al. 1998) and by VEGF in HUVEC (Gliki et al. 2002) involves phosphorylation of Thro5 in the activation loop, and the 
latter is involved in VEGF-stimulated angiogenesis (Gliki et al. 2002). These studies may suggest that activation via Tyr311 phosphorylation may lead to toxic effect, while Thr 505 phosphorylation may be beneficial. Consistent with this hypothesis is the finding that activation of $\mathrm{nPKC} \delta$ by CAMP involves Thr505 and not Tyr ${ }^{311}$ phosphorylation (Schonhoff et al. 2008). Further studies showing that choleretic and cholestatic effects of bile acids depends on nPKC $\delta$ phosphorylation at Thr ${ }^{505}$ and Tyr ${ }^{311}$, respectively, will be required to confirm this hypothesis.

Role of $n P K C \varepsilon$ : $A$ number of cellular processes have been shown to be regulated by ${ }^{n P K C} \varepsilon$, including transporters, endocytosis, exocytosis and tumor progression in cell specific manner (Akita 2002, Akita 2008, Reyland 2009). Of interest to mechanism of bile formation is the postulated role of $\mathrm{nPKC} \varepsilon$ in the regulation of transporters. Thus, PKC $\varepsilon$ may decrease chloride secretion by internalizing Na-K-2Cl cotransporter (Del I et al. 2005) and fluid phase endocytosis in T84 cells (Song et al. 1999). On the other hand, carbachol-induced secretion in lachrymal gland (Jerdeva et al. 2005) is enhanced by nPKC $\varepsilon$. In hepatocytes, choleretic (TCA) as well cholestatic bile acids (GCDCA and TLCA) activate $\mathrm{nPKC} \varepsilon$ (Beuers et al. 1999, Jones et al. 1997, Rao et al. 1997, Stravitz et al. 1996) and $n P K C \varepsilon$ has been suggested to be involved in the cholestatic effect of TLCA. The role of nPKC $\varepsilon$ in the effect of TCA and GCDCA has not been studied directly. TLCA activates $\mathrm{nPKC} \varepsilon$ (Beuers et al. 1999, Schonhoff et al. 2009) and induces Mrp2 retrieval (Nakashima 2002)resulting in decreased solute excretion and bile formation. TUDCA, which reverses TLCA-induced cholestasis (Beuers et al. 2001;Scholmerich et al. 1990) and Mrp2 function (Beuers et al. 2003), inhibits TLCA-induced nPKC $\varepsilon$ activation (Beuers et al. 2003). Our unpublished study showed that CAMP can reverse TLCA-induced Mrp2 retrieval and $\mathrm{nPKC} \varepsilon$ activation in hepatocytes. Thus, PKC $\varepsilon$ may mediate TLCA-induced Mrp2 retrieval, and CAMP and TUDCA may reverse this effect of TLCA by inhibiting TLCA-induced activation of $n P K C \varepsilon$. TLCA also inhibits TCA uptake in hepatocytes (Schwenk et al. 1977) and in HuH-NTCAP cell (Schonhoff et al. 2009). However, TLCA-induced inhibition of TCA uptake is not mediated via $\mathrm{nPKC} \varepsilon$ (Schonhoff et al. 2009). Thus, the canalicular membrane may be the target of $\mathrm{nPKC} \varepsilon$ and this is consistent with the finding that TLCA translocates $\mathrm{nPKC} \varepsilon$ to the canalicular membrane (Beuers et al. 1999).

Mechanism by which TLCA acting via $\mathrm{nPKC} \varepsilon$ induces internalization of Mrp2 is still being determined. One study suggested that this may involve $\mathrm{nPKC} \varepsilon$-mediated phosphorylation of Mrp2 (Wimmer et al. 2008). This study reported that phorbolmyristate acetate, an activator of $\mathrm{cPKCs}$ and $\mathrm{nPKCs}$, can phosphorylate Mrp2 in rat hepatocytes and this is inhibited by staurosporine, an inhibitor of cPKCs and nPKCs. In addition, recombinant $\mathrm{CPKC} \alpha$ and $\mathrm{nPKC} \varepsilon$ phosphorylated MRP2 immunoprecipitated from HepG2 cells in vitro. These results suggest a role for $\mathrm{CPKC} \alpha$ and $\mathrm{nPKC} \varepsilon$ in Mrp2 phosphorylation. It is however not known whether Mrp2 translocation is regulated by its phosphorylation as it has been suggested for Ntcp (Anwer et al. 2007, Anwer et al. 2005). A recent study (Schonhoff et al. 2013) showed that TLCA-induced Mrp2 retrieval may involve PKC $\varepsilon$ mediated phosphorylation of myristoylated alanine-rich $\mathrm{C}$ kinase substrate (MARCKS). MARCKS is a membrane-bound Factin crosslinking protein and is phosphorylated by PKCs(Fujise et al. 1994, Heemskerk et al. 1993). MARCKS phosphorylation has been implicated in endocytosis and this may involve detachment ofphosphorylated MARCKS (pMARCKS) from the membrane (Park et al. 2006). Studies in hepatocytes and HuH-NTCP cells (Schonhoff et al. 2013) showed that TLCA, but not CAMP, increased MARCKS phosphorylation. In HuH-NTCP cells transfected with phosphorylation-deficient MARCKS, TLCA failed to increase MARCKS phosphorylationor decrease plasma membrane MRP2. It is suggested that MRP2 retrieval by TLCA involves TLCA-mediated activation of $n P K C \varepsilon$ followed by MARCKS phosphorylation and consequent detachment of MARCKS from the membrane(Schonhoff et al. 2013). It would appear that TLCA-induced activation of $n P K C \varepsilon$ may result in MRP2 retrieval from the canalicular membrane by at least two different mechanisms. 
Role of aPKC $\zeta$ : This atypical PKC isoform is a downstream effector of PI3K and plays an important role in cell survival signaling (Reyland 2009). Atypical PKC $\zeta$ has been shown to play a cytoprotective role in hepatocytes (Rust et al. 2000). This study showed that TCDCA activated APKC $\zeta$ and inhibition of aPKC $\zeta$ converted TCDCA into a cytotoxic agent. In addition, over expression of wild-type aPKC $\zeta$ blocked GCDCA-induced apoptosis. In addition to its effect on cell survival, $\mathrm{aPKC} \zeta$ has been implicated in cellular metabolism and solute transport in hepatocytes. aPKC $\zeta$ is involved in TCA-induced activation of the insulin signaling pathway via $\mathrm{G}$-protein-coupled receptors (Cao et al. 2010). The PI3K/aPKC $\zeta$ pathway is also involved in cAMP-induced Ntcp translocation to the plasma membrane in hepatocytes (McConkey et al. 2004). So far only one bile acid, TCDCA, has been shown to

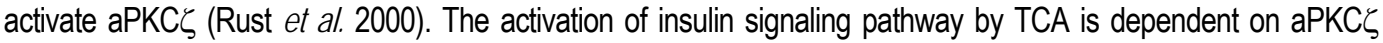

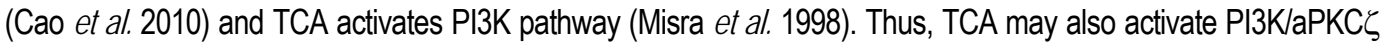
pathway. However, whether $\mathrm{APKC} \zeta$ is involved in the action of other bile acids is unknown at this time.

\section{IIIc. Role of MAPKs:}

MAPKs mediate/regulate diverse cellular functions including embryogenesis, apoptosis, immunity, proliferation, and differentiation by integrating signals from intra- and extracellular stimuli (Cook et al. 2007, Han and Sun, 2007, Kaminska 2005, Raman et al. 2007). Mammalian cells have four major types of MAPKs cascade (Fig. 6) and these include ERK1/2, JNKs, p38 MAPKand ERK5 cascades (Avruch 2007, Keshet and Seger 2010, Krishna and Narang 2008, Morrison 2012). Each of these cascades consists of a core module of three tiers of protein kinases termed MAPK, MAP2K, and MAP3K. There are seven MAP2Ks (also known as MEK, MAP/ERK kinase, or MKK) that differentially activate different MAPKs by dual phosphorylation on Thr and Tyr. Thus, ERK1/2 are activated by MKK1/2, p38 MAPKs are activated by MKK3, MKK4, and MKK6, JNKs by MKK4/7 and ERK5 by MKK5. Activated MAPKs, in turn, phosphorylate and activate transcription factors leading to expression of target genes. The deactivation of MAPKs is achieved through dephosphorylation catalyzed by MAPK-specific phosphatases (MKPs) including dual specific MAPK phosphatases (Caunt and Keyse 2013, Kondoh and Nishida 2007). Choleretic as well as cholestatic bile acids activate ERK1/2 and P38 MAPK and only cholestatic bile acids active JNK1/2 (Table 2). The postulated roles of these kinases in the effect of bile acids are summarized below.

Table 2. Effects of bile acid on MAPKs and the reported effects of MAPKs in hepatic cells

\begin{tabular}{|c|c|c|c|}
\hline & ERK $1 / 2$ & P38 MAPK & JNK1/2 \\
\hline TCA & $\uparrow$ & $\uparrow$ & - \\
\hline TUDCA & $\uparrow$ & $\uparrow$ & - \\
\hline GCDCA & $\uparrow$ & $\uparrow$ & $\uparrow$ \\
\hline DCA & $\uparrow$ & $\uparrow$ & $\uparrow$ \\
\hline TLCA & $\uparrow$ & $\uparrow$ & $\uparrow$ \\
\hline TLCS & $\uparrow$ & $\uparrow$ & $\uparrow$ \\
\hline \multirow[t]{5}{*}{ Effects in hepatic cells } & $\begin{array}{l}\text { Choleresis (Kurz et al. 2000, } \\
\text { Schliess et al. 1997) }\end{array}$ & $\begin{array}{l}\text { Choleresis (Haussinger et al. 2003, } \\
\text { Kubitz et al. 2004b) }\end{array}$ & \multirow{2}{*}{$\begin{array}{l}\text { Apoptosis (Hohenester } \\
\text { et al. 2010, Park et al. } \\
\text { 2007) }\end{array}$} \\
\hline & Anti-apoptosis (Qiao et al. 2002) & Apoptosis (Grambihler et al. 2003) & \\
\hline & \multirow[t]{3}{*}{ Cell polarization (Fu et al. 2011) } & $\begin{array}{l}\text { Anti-apoptosis (Schoemaker et al. } \\
\text { 2004) }\end{array}$ & $\begin{array}{l}\text { Cytoprotection (Qiao et } \\
\text { al. 2003) }\end{array}$ \\
\hline & & $\downarrow$ Cyp7A1(Xu et al. 2007) & \multirow{2}{*}{$\begin{array}{l}\downarrow \text { Cyp7A1 (Gupta et al. } \\
\text { 2001) }\end{array}$} \\
\hline & & Proliferation (Awad et al. 2000) & \\
\hline
\end{tabular}

Both choleretic and cholestatic bile acids activate ERK1/2 and p38 MAPK, and only cholestatic bile acids activate JNK1/2. Activation of ERK1/2 is associated with beneficial effects of bile acids, while activation of JNK1/2 may result in toxic effects of bile acids. Some studies suggest that activation of JNK2 may be cytoprotective. Activation of p38 MAPK is associated with beneficial as well as toxic effects of bile acids. TLCS=Taurolithocholate sulfate 


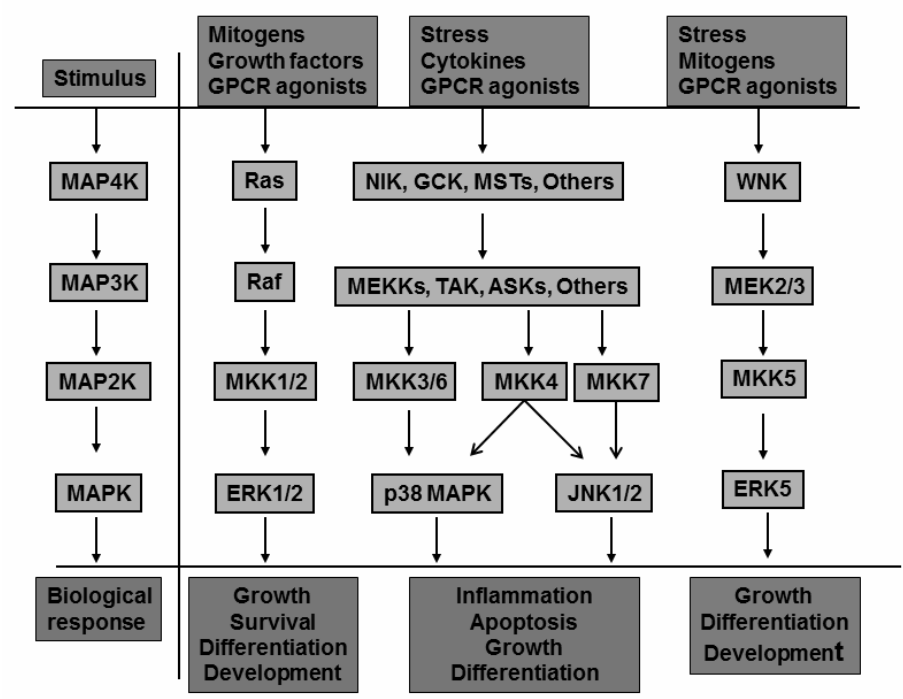

Fig.6. MAPK signaling cascades consist of a core of three sequentially activated protein kinases and these include MAPK kinase kinase (MAP3K), MAPK kinase (MAP2K) and MAPK (Avruch 2007, Keshet and Seger 2010, Krishna and Narang 2008, Raman et al. 2007). In addition, there is an upstream MAPK kinase kinase (MAP4K) and a downstream MAPK activated protein kinase (MAPKAPK, not shown) in certain cells and for certain stimulations, but they are not always necessary for signaling through the cascades. Each cascade is initiated following extracellular stimulus. The extracellular stimuli include growth factors, mitogens, G-protein coupled receptor (GPCR) agonist, stress and inflammatory cytokines. Activation of MAP4K typically involves phosphorylation by protein kinases activated by interaction of an agonist with its cell surface receptor. MAP3K, which is phosphorylated and activated by MAP4K, directly phosphorylates and activates MAP2K (also known as MKK or MEK). Activation of MAPK is then accomplished by dual phosphorylation of a conserved tripeptide (Thr-X-Tyr) motif in the conserved segment by MAP2K. MAP kinases include extracellular signal-regulated kinase (ERK1/2), c-Jun amino-terminal kinases(JNK1/2/3), p38 MAPK and ERK5. Activation of each MAPK leads to a diverse array of biological response.

Role of ERK1/2: Bile acids activate the ERK1/2 signaling pathway and the mechanism of activation differs between conjugated and unconjugated bile acids (Hylemon et al. 2009). The activation by conjugated bile acids may involve activation of the G protein-coupled receptor, S1P receptor 2 (Dent et al. 2005, Fang et al. 2007, Studer et al. 2012). Activation by unconjugated bile acids may involve generation of mitochondrial superoxide ion followed by inactivation of protein phosphatases resulting in the activation of epidermal growth factor receptor (EGFR) and ERK1/2 (Hylemon et al. 2009).Activation of ERK1/2 by bile acids may be involved in cytoprotection from bile acid-induced apoptosis (Qiao et al. 2002), bile acid-mediated hepatocyte polarization (Fu et al. 2011) and stimulation of bile formation (Schliess et al. 1997).Although bile acids activate ERK $1 / 2$ and nuclear receptors in hepatocytes, a cause-effect relationship between these two effects has not been clearly established (Hylemon et al. 2009). Recent studies suggest that bile acids may accelerate development of hepatocyte polarity by activating a signaling pathway that involves activation of ERK1/2 and AMP-kinase (Fu et al. 2011). TUDCA-induced increases in bile acid excretion in perfused rat livers are dependent on ERK1/2 activation and the effect of TUDCA is inhibited by CAMP (Schliess et al. 1997). The effect of CAMP is consistent with a role of ERK pathway in as much as CAMP has been shown to inhibit 
ERK1/2 in hepatocytes (Webster and Anwer 1999). The effect of TUDCA appears to be mediated via a PI3Kdependent activation of Ras/ERK pathway (Kurz et al. 2000) and this pathway is in turn activated by an interaction of TUDCA with integrins resulting in the activation of focal adhesion kinase (FAK)/Src pathway (Haussinger et al. 2003). ERK1/2 is not involved in TCDCA-induced retrieval of NTCP(Muhlfeld et al. 2012). Overall, activation of ERK1/2 pathway appears to mediate beneficial effects of bile acids.

Role of P38 MAPK:The effects of p38MAPK in the liver include regulation of proliferation (Awad et al. 2000), protection against hypoxic injury (Carini et al. 2007), gluconeogenesis (Cao et al. 2005), bile acid synthesis (Xu et al. 2007) and anti-apoptotic effect of TUDCA(Schoemaker et al. 2004), bile acid-induced apoptosis (Grambihler et al. 2003) and biliary excretion of bile acids (Kubitz et al. 2004b). TUDCA-induced increases in bile acid secretion and Bsep translocation to the canalicular membrane require PI3K-independent activation of p38 MAPK (Kubitz et al. 2004b, Kurz et al. 2001). Translocation of Mrp2 by cAMP is also mediated by p38 MAPK (Schonhoff et al. 2010). Interestingly, choleretic (TUDCA, TCA, cAMP) as well as cholestatic (GCDCA, TLCA) agents have been shown to activate p38 MAPK (Graf et al. 2002b, Graf et al. 2003, Grambihler et al. 2003, Kurz et al. 2001, Qiao et al. 2003, Webster et al. 2002a). Thus, p38MAPK appears to mediate both toxic and beneficial effects of bile acids in the liver. One possible explanation for the opposing effects mediated by p38 MAPK may be due to activation of different p38 MAPK isoforms.

There are four known isoforms ( $\alpha, \beta, \gamma$ and $\delta)$ of p38 MAPK and only $\alpha$ and $\beta$ isoforms are expressed in human liver (Jiang et al. 1997). While MKK6 activates all p38 MAPK isoforms, MKK3 does not activate p38 $\beta$ isoform (Enslen et al. 1998, Jiang et al. 1997). Thus, MKK3 is expected to activate $p 38 \alpha$, and not $p 38 \beta$ MAPK in the liver. Cyclic AMP has been shown to specifically activate $p 38 \alpha$, but not $p 38 \beta$ in adipocytes (Robidoux et al. 2005). Selective activation of p38 isoforms has been reported in other cells (Kaminska, 2005, Korb et al. 2006, Wang et al. 2002). Cyclic AMP-induced translocation of Mrp2 in hepatic cells involves activation of MKK3/P38 $\alpha$ MAPK pathway (Schonhoff et al. 2010). While both cAMP and TLCA activate p38 MAPK in mouse hepatocytes, activation of p38MAPK by CAMP, but not byTLCA was inhibited in hepatocytes isolated from MKK3 knockout mice. In addition, CAMP-induced translocation of Mrp2, but not the retrieval of Mrp2 by TLCA was inhibited in hepatocytes from MKK3 knockout mice (unpublished data). These results would suggest that the effect of CAMP, but not TLCA, is mediated via MKK3/P38 $\alpha$ MAPK. Thus, it appears that the beneficial effects of bile acids are mediated via activation of p38 $\alpha$ MAPK. In that case, the toxic effects of bile acids may be mediated via MKK6/p38ß MAPK, respectively. Further studies are needed to test the validity of this hypothesis.

Role of JNKs: There are three isoforms (JNK1, JNK2 and JNK3) of JNK;JNK1and JNK2 are ubiquitous, whereas JNK3 is relatively restricted to brain (Krishna and Narang 2008). JNK proteins are involved in cytokine production, the inflammatory response, stress-induced and developmentally programmed apoptosis, actin reorganization, cell transformation and metabolism (Krishna and Narang 2008, Morrison 2012, Weston and Davis 2007). In hepatocytes, JNK1 and JNK2 are activated by bile acids known to produce toxicity (Graf et al. 2002b, Gupta et al. 2004b, Park et al. 2007, Qiao et al. 2003) and are implicated in bile acid-induced apoptosis (Hohenester et al. 2010, Park et al. 2007, Qiao et al. 2003) and hepatic manifestation of metabolic syndrome (Czaja 2010). Activation of the JNK $1 / 2$ signaling pathway in primary hepatocytes by bile acids has been shown to downregulate CYP7A1 mRNA (Gupta et al. 2001), and thereby decrease bile acid synthesis. Studies to date suggest that JNK1 may mediate toxic effects, while JNK2 may be cytoprotective in certain liver injury (Qiao et al. 2003, Schattenberg et al. 2006, Singh et al. 2009, Tuncman et al. 2006). However, JNK2 activation has also been shown to be involved in liver injury (Schattenberg et al. 2012). Whether JNKs are involved in bile acid induced choleresis and cholestasis has not been studied. 


\section{Future perspective}

Our understanding of the intracellular signaling pathways involved in the regulatory roles played by bile acids is evolving. Recent studies have led to a better understanding of the role of isoforms of PI3K, PKCs and MAPKs in beneficial and toxic effects of bile acids. These studies have led to plausible hypotheses that merit further confirmation and exploration. However, signaling pathways involved in the opposing effects of bile acids are incompletely understood. Thus, it is not known whether the beneficial and toxic effects of bile acids can be explained by a) differential activation of PI3K-p110 $\alpha / \beta$ and PI3K-p110 $\gamma$ isoforms, b) different subcellular localization of aPKC $\alpha, c$ ) differential phosphorylation of $n P K C \delta$, and e) different isoforms of $p 38$ MAPK. It is anticipated that further progress in these areas will allow us to identify specific signaling pathways that are activated by choleretic and cholestatic bile acids. Armed with such information we should be able to design therapeutic approaches to treat cholestasis by targeting specific pathway(s).

\section{Acknowledgement}

This work was supported in part by a grant from US National Institutes of Health grants (NIH-DK 33436 \& $\mathrm{NIH}-\mathrm{DK}$ 90010).

\section{References}

Akita Y. 2002. Protein Kinase C-Epsilon (PKC-Epsilon): Its Unique Structure and Function. J Biochem 132, 847-852. http://dx.doi.org/10.1093/oxfordjournals.jbchem.a003296

Akita Y. 2008. Protein Kinase Cepsilon: Multiple Roles in the Function of, and Signaling Mediated by, the Cytoskeleton. FEBS J 275, 3995-4004. http://dx.doi.org/10.1111/j.1742-4658.2008.06555.x

Amaral JD, Viana RJ, Ramalho RM, Steer CJ, Rodrigues CM. 2009. Bile Acids: Regulation of Apoptosis by Ursodeoxycholic Acid. J Lipid Res 50, 1721-1734. http://dx.doi.org/10.1194/jr.R900011-JLR200

Amaya MJ, Nathanson MH. 2013. Calcium Signaling in the Liver. Compr Physiol 3, 515-539.

Anwer MS (1991) Anatomy and physiology of bile formation, in Biliary Excretion of Drugs and Other Chemicals (Siegers C-P and Watkin JB eds) pp 3-23, G. Fisher Verlag, Stuttgart-New York.

Anwer MS. 1993. Transheptatic Solute Transport and Bile Formation. Adv Vet Sci Comp Med 37,1-29.

Anwer MS. 1998. Cellular and Molecular Biology of the Liver. Curr Opin Gastroenterol 14, 182-190. http://dx.doi.org/10.1097/00001574-199805000-00002.

Anwer MS. 2004. Cellular Regulation of Hepatic Bile Acid Transport in Health and Cholestasis. Hepatology 39, 581-589. http://dx.doi.org/10.1002/hep.20090.

Anwer MS, Ananthanarayanan M, Such FJ (2007) Role of Ntcp phosphorylation in cAMP-mediated stimulation of hepatic bile acid uptake, in Bile Acid: Biological Actions and Clinical Relevance (Keppler D, Beuers U, Leuschner U, Stiehl A, Trauner M and Paumgartner G eds) pp 39-47, Springer, The Netherlands. http://dx.doi.org/10.1007/978-1-40206252-0_5

Anwer MS, Gillin H, Mukhopadhyay S, Balasubramaniyan N, Suchy FJ, Ananthanarayanan M. 2005. Dephosphorylation of Ser-226 Facilitates Plasma Membrane Retention of Ntcp. J Biol Chem 280, 33687-33692. http://dx.doi.org/10.1074/jbc.M502151200.

Avruch J. 2007. MAP Kinase Pathways: the First Twenty Years. Biochim Biophys Acta 1773, 1150-1160. http://dx.doi.org/10.1016/j.bbamcr.2006.11.006.

Awad MM, Enslen H, Boylan JM, Davis RJ, Gruppuso PA. 2000. Growth Regulation Via P38 Mitogen-Activated Protein Kinase in Developing Liver. J Biol Chem 275, 38716-38721. http://dx.doi.org/10.1074/jbc.M008040200. 
Benistant C, Chapuis H, Roche S. 2000. A Specific Function for Phosphatidylinositol 3-Kinase Alpha (P85alphaP110alpha) in Cell Survival and for Phosphatidylinositol 3-Kinase Beta (P85alpha-P110beta) in De Novo DNA Synthesis of Human Colon Carcinoma Cells. Oncogene 19, 5083-5090. http://dx.doi.org/10.1038/sj.onc.1203871.

Beuers U, Bilzer M, Chittattu A, Kullak-Ublick GA, Keppler D, Paumgartner G, Dombrowski F. 2001. Tauroursodeoxycholic Acid Inserts the Apical Conjugate Export Pump, Mrp2, into Canalicular Membranes and Stimulates Organic Anion Secretion by Protein Kinase C-Dependent Mechanisms in Cholestatic Rat Liver. Hepatology 33, 1206-1216. http://dx.doi.org/10.1002/hep.510290227.

Beuers U, Denk GU, Soroka CJ, Wimmer R, Rust C, Paumgartner G, Boyer JL. 2003. Taurolithocholic Acid Exerts Cholestatic Effects Via Phosphatidylinositol-3 Kinase-Dependent Mechanisms in Perfused Rat Livers and Rat Hepatocyte Couplets. J Biol Chem 278,17810-17818. http://dx.doi.org/10.1074/jbc.M209898200.

Beuers U, Probst I, Soroka C, Boyer JL, Kullak-Ublick GA, Paumgartner G. 1999. Modulation of Protein Kinase C by Taurolithocholic Acid in Isolated Rat Hepatocytes. Hepatology 29,477-482. http://dx.doi.org/10.1002/hep.510290227.

Beuers U, Throckmorton DC, Anderson MS, Isales CM, Thasler W, Kullak-Ublick GA, Sauter G, Koebe HG, Paumgartner G, Boyer JL. 1996. Tauroursodeoxycholic Acid Activates Protein Kinase C in Isolated Rat Hepatocytes. Gastroenterology 110, 1553-1563. http://dx.doi.org/10.1053/gast.1996.v110.pm8613063.

Bohan A, Boyer JL. 2002. Mechanisms of Hepatic Transport of Drugs: Implications for Cholestatic Drug Reactions. Semin Liver Dis 22, 123-136. http://dx.doi.org/10.1055/s-2002-30099.

Braiman L, Alt A, Kuroki T, Ohba M, Bak A, Tennenbaum T, Sampson SR. 1999. Protein Kinase Cdelta Mediates InsulinInduced Glucose Transport in Primary Cultures of Rat Skeletal Muscle. Mol Endocrinol 13, 2002-2012. http://dx.doi.org/10.1210/me.13.12.2002.

Brodie C, Blumberg PM. 2003. Regulation of Cell Apoptosis by Protein Kinase c Delta. Apoptosis 8,19-27. http://dx.doi.org/10.1023/A:1021640817208.

Cantley LC. 2002. The Phosphoinositide 3-Kinase Pathway. Science 296, 1655-1657. http://dx.doi.org/10.1126/science.296.5573.1655.

Cao R, Cronk ZX, Zha W, Sun L, Wang X, Fang Y, Studer E, Zhou H, Pandak WM, Dent P, Gil G, Hylemon PB. 2010. Bile Acids Regulate Hepatic Gluconeogenic Genes and Farnesoid X Receptor Via G(Alpha)i-Protein-Coupled Receptors and the AKT Pathway. J Lipid Res 51, 2234-2244. http://dx.doi.org/10.1194/jr.M004929

Cao W, Collins QF, Becker TC, Robidoux J, Lupo EG, Jr., Xiong Y, Daniel KW, Floering L, Collins S. 2005. P38 MitogenActivated Protein Kinase Plays a Stimulatory Role in Hepatic Gluconeogenesis. J Biol Chem 280, 42731-42737. http://dx.doi.org/10.1074/jbc.M506223200

Carini R, Alchera E, Baldanzi G, Piranda D, Splendore R, Grazia De CM, Caraceni P, Graziani A, Albano E. 2007. Role of P38 Map Kinase in Glycine-Induced Hepatocyte Resistance to Hypoxic Injury. J Hepatol 46, 692-699. http://dx.doi.org/10.1016/j.jhep.2006.10.014.

Castello L, Marengo B, Nitti M, Froio T, Domenicotti C, Biasi F, Leonarduzzi G, Pronzato MA, Marinari UM, Poli G, Chiarpotto E. 2005. 4-Hydroxynonenal Signalling to Apoptosis in Isolated Rat Hepatocytes: the Role of PKC-Delta. Biochim Biophys Acta 1737, 83-93. http://dx.doi.org/10.1016/j.bbalip.2005.10.003.

Caunt CJ, Keyse SM. 2013. Dual-Specificity MAP Kinase Phosphatases (MKPs): Shaping the Outcome of MAP Kinase Signalling. FEBS J 280,489-504. http://dx.doi.org/10.1111/j.1742-4658.2012.08716.x.

Chang JD, Sukhova GK, Libby P, Schvartz E, Lichtenstein AH, Field SJ, Kennedy C, Madhavarapu S, Luo J, Wu D, Cantley LC. 2007. Deletion of the Phosphoinositide 3-Kinase P110gamma Gene Attenuates Murine Atherosclerosis. Proc Natl Acad Sci U S A 104, 8077-8082. http://dx.doi.org/10.1073/pnas.0702663104.

Chen CC, Wu ML. 1995. Protein Kinase C Isoform Delta Is Involved in the Stimulation of the $\mathrm{Na}(+)-\mathrm{H}+$ Exchanger in C6 Glioma Cells. Mol Pharmacol 48, 995-1003. 
Cook R, Wu CC, Kang YJ, Han J. 2007. The Role of the P38 Pathway in Adaptive Immunity. Cell Mol Immunol 4, 253259.

Crocenzi FA, Mottino AD, Cao J, Veggi LM, Pozzi EJ, Vore M, Coleman R, Roma MG. 2003a. Estradiol-17beta-DGlucuronide Induces Endocytic Internalization of Bsep in Rats. Am J Physiol Gastrointest Liver Physiol 285, G449G459.

Crocenzi FA, Mottino AD, Sanchez Pozzi EJ, Pellegrino JM, Rodriguez Garay EA, Milkiewicz P, Vore M, Coleman R, Roma MG. 2003b. Impaired Localisation and Transport Function of Canalicular Bsep in Taurolithocholate Induced Cholestasis in the Rat. Gut 52,1170-1177. http://dx.doi.org/10.1136/gut.52.8.1170.

Czaja MJ. 2010. JNK Regulation of Hepatic Manifestations of the Metabolic Syndrome. Trends Endocrinology Metabolism 21,707-713. http://dx.doi.org/10.1016/j.tem.2010.08.010.

Del C, I, Fedor-Chaiken M, Song JC, Starlinger V, Yoo J, Matlin KS, Matthews JB. 2005. Dynamic Regulation of $\mathrm{Na}(+)-$ $\mathrm{K}(+)-2 \mathrm{Cl}(-)$ Cotransporter Surface Expression by PKC-\{Epsilon\} in $\mathrm{Cl}(-)-$-Secretory Epithelia. Am J Physiol Cell Physiol 289, C1332-C1342. http://dx.doi.org/10.1152/ajpcell.00580.2004.

Dent P, Fang Y, Gupta S, Studer E, Mitchell C, Spiegel S, Hylemon PB. 2005. Conjugated Bile Acids Promote ERK1/2 and AKT Activation Via a Pertussis Toxin-Sensitive Mechanism in Murine and Human Hepatocytes. Hepatology 42,1291-1299. http://dx.doi.org/10.1002/hep.20942.

Elferink RO, Groen AK. 2002. Genetic Defects in Hepatobiliary Transport. Biochim Biophys Acta 1586,129-145. http://dx.doi.org/10.1016/S0925-4439\%2801\%2900103-X.

Elmendorf JS. 2002. Signals That Regulate GLUT4 Translocation. J Membr Biol 190,167-174. http://dx.doi.org/10.1007/s00232-002-1035-3.

Enslen H, Raingeaud J, Davis RJ. 1998. Selective Activation of P38 Mitogen-Activated Protein (MAP) Kinase Isoforms by the MAP Kinase Kinases MKK3 and MKK6. J Biol Chem 273, 1741-1748. http://dx.doi.org/10.1074/jbc.273.3.1741.

Fang Y, Studer E, Mitchell C, Grant S, Pandak WM, Hylemon PB, Dent P. 2007. Conjugated Bile Acids Regulate Hepatocyte Glycogen Synthase Activity in Vitro and in Vivo Via Galphai Signaling. Mol Pharmacol 71, 1122-1128. http://dx.doi.org/10.1124/mol.106.032060.

Fischer L, Gukovskaya AS, Penninger JM, Mareninova OA, Friess H, Gukovsky I, Pandol SJ. 2007. Phosphatidylinositol 3-Kinase Facilitates Bile Acid-Induced $\mathrm{Ca}(2+)$ Responses in Pancreatic Acinar Cells. Am J Physiol Gastrointest Liver Physiol 292, G875-G886. http://dx.doi.org/10.1152/ajpgi.00558.2005.

Folli F, Alvaro D, Gigliozzi A, Bassotti C, Kahn CR, Pontiroli AE, Capocaccia L, Jezequel AM, Benedetti A. 1997. Regulation of Endocytic-Transcytotic Pathways and Bile Secretion by Phosphatidylinositiol 3-Kinase in Rats. Gastroenterology 113, 954-965. http://dx.doi.org/10.1016/S0016-5085\%2897\%2970192-6.

Foukas LC, Claret M, Pearce W, Okkenhaug K, Meek S, Peskett E, Sancho S, Smith AJ, Withers DJ, Vanhaesebroeck B. 2006. Critical Role for the P110alpha Phosphoinositide-3-OH Kinase in Growth and Metabolic Regulation. Nature 441, 366-370. http://dx.doi.org/10.1038/nature04694.

Fu D, Lippincott-Schwartz J, Arias IM. 2011. Cellular Mechanism of Bile Acid-Accelerated Hepatocyte Polarity. Small GTPases 2, 314-317. http://dx.doi.org/10.4161/sgtp.18087.

Fujise A, Mizuno K, Ueda Y, Osada S, Hirai S, Takayanagi A, Shimizu N, Owada MK, Nakajima H, Ohno S. 1994. Specificity of the High Affinity Interaction of Protein Kinase C With a Physiological Substrate, Myristoylated AlanineRich Protein Kinase C Substrate. J Biol Chem 269, 31642-31648.

Gates A, Hohenester S, Anwer MS, Webster CR. 2009. CAMP-GEF Cytoprotection by Src Tyrosine Kinase Activation of Phosphoinositide-3-Kinase P110 \{Beta\}/\{Alpha\} in Rat Hepatocytes. Am J Physiol Gastrointest Liver Physiol 296, G764-G774. http://dx.doi.org/10.1152/ajpgi.90622.2008. 
Gliki G, Wheeler-Jones C, Zachary I. 2002. Vascular Endothelial Growth Factor Induces Protein Kinase C (PKC)Dependent Akt/PKB Activation and Phosphatidylinositol 3'-Kinase-Mediates PKC Delta Phosphorylation: Role of PKC in Angiogenesis. Cell Biol Int 26, 751-759. http://dx.doi.org/10.1016/S1065-6995\%2802\%2990926-1.

Go YM, Park H, Maland MC, Darley-Usmar VM, Stoyanov B, Wetzker R, Jo H. 1998. Phosphatidylinositol 3-Kinase Gamma Mediates Shear Stress-Dependent Activation of JNK in Endothelial Cells. Am J Physiol 275,H1898-H1904.

Graf D, Kurz AK, Fischer R, Reinehr R, Haussinger D. 2002a. Taurolithocholic Acid-3 Sulfate Induces CD95 Trafficking and Apoptosis in a C-Jun N-Terminal Kinase-Dependent Manner. Gastroenterology 122, 1411-1427. http://dx.doi.org/10.1053/gast.2002.32976.

Graf D, Kurz AK, Reinehr R, Fischer R, Kircheis G, Haussinger D. 2002b. Prevention of Bile Acid-Induced Apoptosis by Betaine in Rat Liver. Hepatology 36, 829-839. http://dx.doi.org/10.1016/S0270-9139\%2802\%2900089-7.

Graf D, Reinehr R, Kurz AK, Fischer R, Haussinger D. 2003. Inhibition of Taurolithocholate 3-Sulfate-Induced Apoptosis by Cyclic AMP in Rat Hepatocytes Involves Protein Kinase A-Dependent and -Independent Mechanisms. Arch Biochem Biophys 415, 34-42. http://dx.doi.org/10.1016/S0003-9861\%2803\%2900224-8.

Grambihler A, Higuchi H, Bronk SF, Gores GJ. 2003. CFLIP-L Inhibits P38 MAPK Activation: an Additional Anti-Apoptotic Mechanism in Bile Acid-Mediated Apoptosis. J Biol Chem 278, 26831-26837. http://dx.doi.org/10.1074/jbc.M303229200

Guillermet-Guibert J, Bjorklof K, Salpekar A, Gonella C, Ramadani F, Bilancio A, Meek S, Smith AJ, Okkenhaug K, Vanhaesebroeck B. 2008. The P110beta Isoform of Phosphoinositide 3-Kinase Signals Downstream of G ProteinCoupled Receptors and Is Functionally Redundant With P110gamma. Proc Natl Acad Sci U S A 105, 8292-8297. http://dx.doi.org/10.1073/pnas.0707761105.

Gupta S, Natarajan R, Payne SG, Studer EJ, Spiegel S, Dent P, Hylemon PB. 2004a. Deoxycholic Acid Activates the CJun N-Terminal Kinase Pathway Via FAS Receptor Activation in Primary Hepatocytes. Role of Acidic Sphingomyelinase-Mediated Ceramide Generation in FAS Receptor Activation. J Biol Chem 279, 5821-5828. http://dx.doi.org/10.1074/jbc.M310979200.

Gupta S, Natarajan R, Payne SG, Studer EJ, Spiegel S, Dent P, Hylemon PB. 2004b. Deoxycholic Acid Activates the CJun N-Terminal Kinase Pathway Via FAS Receptor Activation in Primary Hepatocytes. Role of Acidic Sphingomyelinase-Mediated Ceramide Generation in FAS Receptor Activation. J Biol Chem 279, 5821-5828. http://dx.doi.org/10.1074/jbc.M310979200.

Gupta S, Stravitz RT, Dent P, Hylemon PB. 2001. Down-Regulation of Cholesterol 7alpha-Hydroxylase (CYP7A1) Gene Expression by Bile Acids in Primary Rat Hepatocytes Is Mediated by the C-Jun N-Terminal Kinase Pathway. J Biol Chem 276, 15816-15822. http://dx.doi.org/10.1074/jbc.M010878200.

Hagenbuch B and Meier PJ. 2003. The Superfamily of Organic Anion Transporting Polypeptides. Biochim Biophys Acta 1609:1-18. http://dx.doi.org/10.1016/S0005-2736\%2802\%2900633-8

Han J, Sun P. 2007. The Pathways to Tumor Suppression Via Route P38. Trends Biochem Sci 32, 364-371. http://dx.doi.org/10.1016/j.tibs.2007.06.007.

Haussinger D, Kurz AK, Wettstein M, Graf D, vom DS, Schliess F. 2003. Involvement of Integrins and Src in Tauroursodeoxycholate-Induced and Swelling-Induced Choleresis. Gastroenterology 124, 1476-1487. http://dx.doi.org/10.1016/S0016-5085\%2803\%2900274-9.

Hawkins PT, Stephens LR. 2007. PI3Kgamma Is a Key Regulator of Inflammatory Responses and Cardiovascular Homeostasis. Science 318, 64-66. http://dx.doi.org/10.1126/science.1145420.

Heemskerk FM, Chen HC, Huang FL. 1993. Protein Kinase C Phosphorylates Ser152, Ser156 and Ser163 but Not Ser160 of MARCKS in Rat Brain. Biochem Biophys Res Commun 190, 236-241. http://dx.doi.org/10.1006/bbrc.1993.1036.

Hofmann AF. 1999. Bile Acids: The Good, the Bad, and the Ugly. News Physiol Sci 14, 24-29. 
Hofmann AF. 2009. The Enterohepatic Circulation of Bile Acids in Mammals: Form and Functions. Front Biosci 14, 25842598. http://dx.doi.org/10.2741/3399.

Hofmann AF, Hagey LR. 2008. Bile Acids: Chemistry, Pathochemistry, Biology, Pathobiology, and Therapeutics. Cell Mol Life Sci 65, 2461-2483. http://dx.doi.org/10.1007/s00018-008-7568-6.

Hohenester S, Gates A, Wimmer R, Beuers U, Anwer MS, Rust C, Webster CR. 2010. Phosphatidylinositol-3-Kinase P110gamma Contributes to Bile Salt-Induced Apoptosis in Primary Rat Hepatocytes and Human Hepatoma Cells. J Hepatol 53, 918-926. http://dx.doi.org/10.1016/j.jhep.2010.05.015.

Hylemon PB, Zhou H, Pandak WM, Ren S, Gil G, Dent P. 2009. Bile Acids As Regulatory Molecules. J Lipid Res 50, 1509-1520. http://dx.doi.org/10.1194/jlr.R900007-JLR200.

Jackson DN, Foster DA. 2004. The Enigmatic Protein Kinase Cdelta: Complex Roles in Cell Proliferation and Survival. FASEB J 18, 627-636. http://dx.doi.org/10.1096/fj.03-0979rev.

Jansen PL, Muller M, Sturm E. 2001. Genes and Cholestasis. Hepatology 34,1067-1074. http://dx.doi.org/10.1053/jhep.2001.29625.

Jerdeva GV, Yarber FA, Trousdale MD, Rhodes CJ, Okamoto CT, Dartt DA, Hamm-Alvarez SF. 2005. DominantNegative PKC-Epsilon Impairs Apical Actin Remodeling in Parallel With Inhibition of Carbachol-Stimulated Secretion in Rabbit Lacrimal Acini. Am J Physiol Cell Physiol 289, C1052-C1068. http://dx.doi.org/10.1152/ajpcell.00546.2004.

Jia S, Liu Z, Zhang S, Liu P, Zhang L, Lee SH, Zhang J, Signoretti S, Loda M, Roberts TM, Zhao JJ. 2008. Essential Roles of PI(3)K-P110beta in Cell Growth, Metabolism and Tumorigenesis. Nature 454, 776-779.

Jiang Y, Gram H, Zhao M, New L, Gu J, Feng L, Di PF, Ulevitch RJ, Han J. 1997. Characterization of the Structure and Function of the Fourth Member of P38 Group Mitogen-Activated Protein Kinases, P38delta. J Biol Chem 272, 30122-30128. http://dx.doi.org/10.1074/jbc.272.48.30122.

Jones BA, Rao YP, Stravitz RT, Gores GJ. 1997. Bile Salt-Induced Apoptosis of Hepatocytes Involves Activation of Protein Kinase C. Am J Physiol 272, G1109-G1115.

Kaminska B. 2005. MAPK Signalling Pathways As Molecular Targets for Anti-Inflammatory Therapy--From Molecular Mechanisms to Therapeutic Benefits. Biochim Biophys Acta 1754, 253-262. http://dx.doi.org/10.1016/j.bbapap.2005.08.017.

Kanno N, Lesage G, Glaser S, Alpini G. 2001. Regulation of Cholangiocyte Bicarbonate Secretion. Am J Physiol Gastrointest Liver Physiol 281, G612-G625.

Keshet Y and Seger R. 2010. The MAP Kinase Signaling Cascades: a System of Hundreds of Components Regulates a Diverse Array of Physiological Functions. Methods Mol Biol 661:3-38. http://dx.doi.org/10.1007/978-1-60761-795-2_1

Kondoh K, Nishida E. 2007. Regulation of MAP Kinases by MAP Kinase Phosphatases. Biochim Biophys Acta 1773, 1227-1237. http://dx.doi.org/10.1016/j.bbamcr.2006.12.002.

Konopatskaya O, Poole AW. 2010. Protein Kinase Calpha: Disease Regulator and Therapeutic Target. Trends Pharmacol Sci 31, 8-14. http://dx.doi.org/10.1016/j.tips.2009.10.006.

Korb A, Tohidast-Akrad M, Cetin E, Axmann R, Smolen J, Schett G. 2006. Differential Tissue Expression and Activation of P38 MAPK Alpha, Beta, Gamma, and Delta Isoforms in Rheumatoid Arthritis. Arthritis Rheum 54, 2745-2756. http://dx.doi.org/10.1002/art.22080.

Kosters A, Karpen SJ. 2008. Bile Acid Transporters in Health and Disease. Xenobiotica 38, 1043-1071. http://dx.doi.org/10.1080/00498250802040584.

Krishna M, Narang H. 2008. The Complexity of Mitogen-Activated Protein Kinases (MAPKs) Made Simple. Cell Mol Life Sci 65, 3525-3544. http://dx.doi.org/10.1007/s00018-008-8170-7. 
Kubitz R, Saha N, Kuhlkamp T, Dutta S, vom DS, Wettstein M, Haussinger D. 2004a. Ca2+-Dependent Protein Kinase C Isoforms Induce Cholestasis in Rat Liver. J Biol Chem 279,10323-10330. http://dx.doi.org/10.1074/jbc.M306242200.

Kubitz R, Sutfels G, Kuhlkamp T, Kolling R, Haussinger D. 2004b. Trafficking of the Bile Salt Export Pump From the Golgi to the Canalicular Membrane Is Regulated by the P38 MAP Kinase. Gastroenterology 126,541-553. http://dx.doi.org/10.1053/j.gastro.2003.11.003.

Kurz AK, Block C, Graf D, Dahl SV, Schliess F, Haussinger D. 2000. Phosphoinositide 3-Kinase-Dependent Ras Activation by Tauroursodesoxycholate in Rat Liver. Biochem J 350, 207-213. http://dx.doi.org/10.1042/02646021:3500207.

Kurz AK, Graf D, Schmitt M, Dahl SV, Haussinger D. 2001. Tauroursodesoxycholate-Induced Choleresis Involves P38(MAPK) Activation and Translocation of the Bile Salt Export Pump in Rats. Gastroenterology 121, 407-419. http://dx.doi.org/10.1053/gast.2001.26262.

Lali FV, Hunt AE, Turner SJ, Foxwell BM. 2000. The Pyridinyl Imidazole Inhibitor SB203580 Blocks PhosphoinositideDependent Protein Kinase Activity, Protein Kinase B Phosphorylation, and Retinoblastoma Hyperphosphorylation in Interleukin-2-Stimulated T Cells Independently of P38 Mitogen-Activated Protein Kinase. J Biol Chem 275, 73957402. http://dx.doi.org/10.1074/jbc.275.10.7395.

Le Good JA, Ziegler WH, Parekh DB, Alessi DR, Cohen P, Parker PJ. 1998. Protein Kinase C Isotypes Controlled by Phosphinositide 3-Kinase Through the Protein Kinsae PDK1. Science 281, 2042-2045.

Lee J, Boyer JL. 2000. Molecular Alterations in Hepatocyte Transport Mechanisms in Acquired Cholestatic Liver Disorders. Semin Liver Dis 20:373-384. http://dx.doi.org/10.1126/science.281.5385.2042.

Liedtke CM,Cole T. 1997. Antisense Oligodeoxynucleotide to PKC-Delta Blocks Alpha 1-Adrenergic Activation of Na-K2Cl Cotransport. Am J Physiol 273, C1632-C1640.

Lu W, Finnis S, Xiang C, Lee HK, Markowitz Y, Okhrimenko H, Brodie C. 2007. Tyrosine 311 Is Phosphorylated by C-Abl and Promotes the Apoptotic Effect of PKCdelta in Glioma Cells. Biochem Biophys Res Commun 352, 431-436. http://dx.doi.org/10.1016/j.bbrc.2006.11.028

Lupia E, Goffi A, De GP, Azzolino O, Bosco O, Patrucco E, Vivaldo MC, Ricca M, Wymann MP, Hirsch E, Montrucchio G, Emanuelli G. 2004. Ablation of Phosphoinositide 3-Kinase-Gamma Reduces the Severity of Acute Pancreatitis. Am J Pathol 165, 2003-2011. http://dx.doi.org/10.1016/S0002-9440\%2810\%2963251-8.

Maddox JF, Roth RA, Ganey PE. 2003. Allyl Alcohol Activation of Protein Kinase C Delta Leads to Cytotoxicity of Rat Hepatocytes. Chem Res Toxicol 16, 609-615. http://dx.doi.org/10.1021/tx025655n.

Maillette de Buy WL, Beuers U. 2010. Bile Salts and Cholestasis. Dig Liver Dis 42, 409-418. http://dx.doi.org/10.1016/j.dld.2010.03.015.

McConkey M, Gillin H, Webster CR, Anwer MS. 2004. Cross-Talk Between Protein Kinases Czeta and B in Cyclic AMPMediated Sodium Taurocholate Co-Transporting Polypeptide Translocation in Hepatocytes. J Biol Chem 279, 20882-20888. http://dx.doi.org/10.1074/jbc.M309988200.

Mennone A, Biemesderfer D, Negoianu D, Yang CL, Abbiati T, Schultheis PJ, Shull GE, Aronson PS, Boyer JL. 2001. Role of Sodium/Hydrogen Exchanger Isoform NHE3 in Fluid Secretion and Absorption in Mouse and Rat Cholangiocytes. Am J Physiol Gastrointest Liver Physiol 280, G247-G254.

Michalczyk I, Sikorski AF, Kotula L, Junghans RP, Dubielecka PM. 2013. The Emerging Role of Protein Kinase Ctheta in Cytoskeletal Signaling. J Leukoc Biol 93, 319-327. http://dx.doi.org/10.1189/jlb.0812371.

Misra S, Ujházy P, Gatmaitan Z, Varticovski L and Arias IM. 1998. The Role of Phophoinositide 3-Kinase in Taurocholate-Induced Trafficking of ATP-Dependent Canalicular Transporters in Rat Liver. J Biol Chem 273:26638-26644. http://dx.doi.org/10.1074/jbc.273.41.26638.

Morrison DK. 2012. MAP Kinase Pathways. Cold Spring Harb Perspect Biol 4. 
Mottino AD, Cao J, Veggi LM, Crocenzi F, Roma MG, Vore M. 2002. Altered Localization and Activity of Canalicular Mrp2 in Estradiol-17beta-D-Glucuronide-Induced Cholestasis. Hepatology 35,1409-1419. http://dx.doi.org/10.1053/jhep.2002.33327.

Muhlfeld S, Domanova O, Berlage T, Stross C, Helmer A, Keitel V, Haussinger D, Kubitz R. 2012. Short-Term Feedback Regulation of Bile Salt Uptake by Bile Salts in Rodent Liver. Hepatology 56, 387-2397. http://dx.doi.org/10.1002/hep.25955.

Nakashima S. 2002. Protein Kinase C Alpha (PKC Alpha): Regulation and Biological Function. J Biochem 132, 669-675. http://dx.doi.org/10.1093/oxfordjournals.jbchem.a003272.

Nathanson MH, Boyer JL. 1991. Mechanisms and Regulation of Bile Secretion. Hepatology 14, 551-556. http://dx.doi.org/10.1002/hep.1840140324.

Newton AC. 2003. Regulation of the ABC Kinases by Phosphorylation: Protein Kinase C As a Paradigm. Biochem J 370 , 361-371. http://dx.doi.org/10.1042/BJ20021626.

Newton AC. 2010. Protein Kinase C: Poised to Signal. Am J Physiol Endocrinol Metab 298, E395-E402. http://dx.doi.org/10.1152/ajpendo.00477.2009.

Nguyen A and Bouscarel B. 2008. Bile Acids and Signal Transduction: Role in Glucose Homeostasis. Cell Signal 20, 2180-2197. http://dx.doi.org/10.1016/j.cellsig.2008.06.014

Park EJ, Zhao YZ, Kim YC,Sohn DH. 2007. PF2401-SF, Standardized Fraction of Salvia Miltiorrhiza and Its Constituents, Tanshinone I, Tanshinone IIA, and Cryptotanshinone, Protect Primary Cultured Rat Hepatocytes From Bile AcidInduced Apoptosis by Inhibiting JNK Phosphorylation. Food Chem Toxicol 45, 891-1898. http://dx.doi.org/10.1016/j.fct.2007.04.005.

Park SW, Schonhoff CM, Webster CR, Anwer MS. 2012. Protein Kinase Cdelta Differentially Regulates CAMPDependent Translocation of NTCP and MRP2 to the Plasma Membrane. Am J Physiol Gastrointest Liver Physiol 303, G657-G665. http://dx.doi.org/10.1152/ajpgi.00529.2011.

Park YS, Hur EM, Choi BH, Kwak E, Jun DJ, Park SJ, Kim KT. 2006. Involvement of Protein Kinase C-Epsilon in ActivityDependent Potentiation of Large Dense-Core Vesicle Exocytosis in Chromaffin Cells. J Neurosci 26, 8999-9005. http://dx.doi.org/10.1523/JNEUROSCI.2828-06.2006.

Paumgartner G, Beuers U. 2004. Mechanisms of Action and Therapeutic Efficacy of Ursodeoxycholic Acid in Cholestatic Liver Disease. Clin Liver Dis 8, 67-81. http://dx.doi.org/10.1016/S1089-3261\%2803\%2900135-1.

Perez LM, Milkiewicz P, Elias E, Coleman R, Sanchez Pozzi EJ, Roma MG. 2006. Oxidative Stress Induces Internalization of the Bile Salt Export Pump, Bsep, and Bile Salt Secretory Failure in Isolated Rat Hepatocyte Couplets: a Role for Protein Kinase C and Prevention by Protein Kinase A. Toxicol Sci 91,150-158. http://dx.doi.org/10.1093/toxsci/kfj113.

Perez MJ, Briz O. 2009. Bile-Acid-Induced Cell Injury and Protection. World J Gastroenterol 15,677-1689. http://dx.doi.org/10.3748/wjg.15.1677.

Pols TW, Noriega LG, Nomura M, Auwerx J, Schoonjans K. 2011. The Bile Acid Membrane Receptor TGR5 As an Emerging Target in Metabolism and Inflammation. J Hepatol 54, 1263-1272. http://dx.doi.org/10.1016/j.jhep.2010.12.004.

Pretorius L, Owen KL,McMullen JR. 2009. Role of Phosphoinositide 3-Kinases in Regulating Cardiac Function. Front Biosci 14, 2221-2229. http://dx.doi.org/10.2741/3374.

Qiao L, Han SI, Fang Y, Park JS, Gupta S, Gilfor D, Amorino G, Valerie K, Sealy L, Engelhardt JF, Grant S, Hylemon PB Dent P. 2003. Bile Acid Regulation of C/EBPbeta, CREB, and C-Jun Function, Via the Extracellular SignalRegulated Kinase and C-Jun NH2-Terminal Kinase Pathways, Modulates the Apoptotic Response of Hepatocytes. Mol Cell Biol 23, 3052-3066. http://dx.doi.org/10.1128/MCB.23.9.3052-3066.2003. 
Qiao L, Yacoub A, Studer E, Gupta S, Pei XY, Grant S, Hylemon PB, Dent P. 2002. Inhibition of the MAPK and PI3K Pathways Enhances UDCA-Induced Apoptosis in Primary Rodent Hepatocytes. Hepatology 35, 79-789. http://dx.doi.org/10.1053/jhep.2002.32533.

Raman M, Chen W and Cobb MH. 2007. Differential Regulation and Properties of MAPKs. Oncogene 26:3100-3112. http://dx.doi.org/10.1038/sj.onc.1210392.

Rameh LE, Cantley LC. 1999. The Role of Phosphoinositide 3-Kinase Lipid Products in Cell Function. J Biol Chem 274, 8347-8350. http://dx.doi.org/10.1074/jbc.274.13.8347.

Rao YP, Stravitz RT, Vlahcevic ZR, Gurley EC, Sando JJ, Hylemon PB. 1997. Activation of Protein Kinase C Alpha and Delta by Bile Acids: Correlation With Bile Acid Structure and Diacylglycerol Formation. J Lipid Res 38, 2446-2454.

Reyland ME. 2009. Protein Kinase C Isoforms: Multi-Functional Regulators of Cell Life and Death. Front Biosci 14, 23862399. http://dx.doi.org/10.2741/3385.

Robidoux J, Cao W, Quan H, Daniel KW, Moukdar F, Bai X, Floering LM, Collins S. 2005. Selective Activation of Mitogen-Activated Protein (MAP) Kinase Kinase 3 and P38alpha MAP Kinase Is Essential for Cyclic AMPDependent UCP1 Expression in Adipocytes. Mol Cell Biol 25, 5466-5479. http://dx.doi.org/10.1128/MCB.25.13.54665479.2005 .

Rust C, Bauchmuller K, Fickert P, Fuchsbichler A, Beuers U. 2005. Phosphatidylinositol 3-Kinase-Dependent Signaling Modulates Taurochenodeoxycholic Acid-Induced Liver Injury and Cholestasis in Perfused Rat Livers. Am J Physiol Gastrointest Liver Physiol 289, G88-G94. http://dx.doi.org/10.1152/ajpgi.00450.2004.

Rust C, Karnitz LM, Paya CV, Moscat J, Simari RD, Gores GJ. 2000. The Bile Acid Taurochenodeoxycholate Activates a Phosphatidylinositol 3- Kinase-Dependent Survival Signaling Cascade. J Biol Chem 275, 20210-20216. http://dx.doi.org/10.1074/jbc.M909992199.

Saksena S, Gill RK, Tyagi S, Alrefai WA, Sarwar Z, Ramaswamy K, Dudeja PK. 2005. Involvement of C-Src and Protein Kinase $\mathrm{C}$ Delta in the Inhibition of $\mathrm{Cl}(-) / \mathrm{OH}$ - Exchange Activity in Caco-2 Cells by Serotonin. J Biol Chem 280,11859-11868. http://dx.doi.org/10.1074/jbc.M411553200.

Schattenberg JM, Nagel M, Kim YO, Kohl T, Worns MA, Zimmermann T, Schad A, Longerich T, Schuppan D, He YW, Galle PR,Schuchmann M. 2012. Increased Hepatic Fibrosis and JNK2-Dependent Liver Injury in Mice Exhibiting Hepatocyte-Specific Deletion of CFLIP. Am J Physiol Gastrointest Liver Physiol 303, G498-G506. http://dx.doi.org/10.1152/ajpgi.00525.2011.

Schattenberg JM, Singh R, Wang Y, Lefkowitch JH, Rigoli RM, Scherer PE, Czaja MJ. 2006. JNK1 but Not JNK2 Promotes the Development of Steatohepatitis in Mice. Hepatology 43:163-172. http://dx.doi.org/10.1002/hep.20999.

Schiff M. 1870. Gallebildung, Abhaengig Von Der Aufsaugung Der Gallenstoffe. Gesamte Physiol Menschen Tiere 3, 598-613. http://dx.doi.org/10.1007/BF01855780.

Schliess F, Kurz AK, vom Dahl S, Haussinger D. 1997. Mitogen-Activated Protein Kinase Mediate the Stimulation of Bile Acid Secretion by Tauroursodeoxycholate in Rat Liver. Gastroenterology 113,1306-1313. http://dx.doi.org/10.1053/gast.1997.v113.pm9322526.

Schoemaker MH, Conde de la RL, Buist-Homan M, Vrenken TE, Havinga R, Poelstra K, Haisma HJ, Jansen PL, Moshage H. 2004. Tauroursodeoxycholic Acid Protects Rat Hepatocytes From Bile Acid-Induced Apoptosis Via Activation of Survival Pathways. Hepatology 39, 1563-1573. http://dx.doi.org/10.1002/hep.20246.

Scholmerich J, Baumgartner U, Miyai K, Gerok W. 1990. Tauroursodeoxycholate Prevents Taurolithocholate-Induced Cholestasis and Toxicity in Rat Liver. J Hepatol 10, 280-283.

Schonhoff CM, Gillin H, Webster CR,Anwer MS. 2008. Protein Kinase Cdelta Mediates Cyclic Adenosine Monophosphate-Stimulated Translocation of Sodium Taurocholate Cotransporting Polypeptide and Multidrug Resistant Associated Protein 2 in Rat Hepatocytes. Hepatology 47, 1309-1316. http://dx.doi.org/10.1002/hep.22162. 
Schonhoff CM, Webster CR, Anwer MS. 2010. Cyclic AMP Stimulates Mrp2 Translocation by Activating P38\{Alpha\} MAPK in Hepatic Cells. Am J Physiol Gastrointest Liver Physiol 298, G667-G674.

Schonhoff CM, Webster CR, Anwer MS. 2013. Taurolithocholate-Induced MRP2 Retrieval Involves MARCKS Phosphorylation by Protein Kinase $C$ in HUH-NTCP Cells. Hepatology 58,284-292. http://dx.doi.org/10.1002/hep.26333.

Schonhoff CM, Yamazaki A, Hohenester S, Webster CR, Bouscarel B, Anwer MS. 2009. PKC\{Epsilon\}-Dependent and Independent Effects of Taurolithocholate on PI3K/PKB Pathway and Taurocholate Uptake in HuH-NTCP Cell Line. Am J Physiol Gastrointest Liver Physiol 297, G1259-G1267. http://dx.doi.org/10.1152/ajpgi.00177.2009.

Schwenk M, Schwarz LR, Greim H. 1977. Taurolithocholate Inhibits Taurocholate Uptake by Isolated Hepatocytes at Low Concentrations. Naunyn Schmiedebergs Arch Pharmacol 298,175-179. http://dx.doi.org/10.1007/BF00508626.

Singh R, Wang Y, Xiang Y, Tanaka KE, Gaarde WA, Czaja MJ. 2009. Differential Effects of JNK1 and JNK2 Inhibition on Murine Steatohepatitis and Insulin Resistance. Hepatology 49, 87-96. http://dx.doi.org/10.1002/hep.22578.

Singh SK, Mennone A, Gigliozzi A, Fraioli F, Boyer JL. 2001. Cl(-)-Dependent Secretory Mechanisms in Isolated Rat Bile Duct Epithelial Units. Am J Physiol Gastrointest Liver Physiol 281, G438-G446.

Song JC, Hrnjez BJ, Farokhzad OC, Matthews JB. 1999. PKC-Epsilon Regulates Basolateral Endocytosis in Human T84 Intestinal Epithelia: Role of F-Actin and MARCKS. Am J Physiol 277, C1239-C1249.

Stravitz RT, Rao YP, Vlahcevic ZR, Gurley EC, Jarvis WD,Hylemon PB. 1996. Hepatocellular Protein Kinase C Activation by Bile Acids: Implications for Regulation of Cholesterol 7 Alpha-Hydroxylase. Am J Physiol 271, G293-G303.

Stross C, Helmer A, Weissenberger K, Gorg B, Keitel V, Haussinger D, Kubitz R. 2010. Protein Kinase C Induces Endocytosis of the Sodium Taurocholate Cotransporting Polypeptide. Am J Physiol Gastrointest Liver Physiol 299, G320-G328. http://dx.doi.org/10.1152/ajpgi.00180.2010.

Studer E, Zhou X, Zhao R, Wang Y, Takabe K, Nagahashi M, Pandak WM, Dent P, Spiegel S, Shi R, Xu W, Liu X, Bohdan P, Zhang L, Zhou H, Hylemon PB. 2012. Conjugated Bile Acids Activate the Sphingosine-1-Phosphate Receptor 2 in Primary Rodent Hepatocytes. Hepatology 55, 267-276. http://dx.doi.org/10.1002/hep.24681.

Tan SL, Parker PJ. 2003. Emerging and Diverse Roles of Protein Kinase C in Immune Cell Signalling. Biochem J 376 , 545-552. http://dx.doi.org/10.1042/BJ20031406.

Toker A. 2000. Protein Kinases As Mediators of Phosphoinositide 3-Kinase Signaling. Mol Pharmacol 57:652-658.

Trauner M, Boyer JL. 2003. Bile Salt Transporters: Molecular Characterization, Function, and Regulation. Physiol Rev 83, 633-671.

Tuncman G, Hirosumi J, Solinas G, Chang L, Karin M, Hotamisligil GS. 2006. Functional in Vivo Interactions Between JNK1 and JNK2 Isoforms in Obesity and Insulin Resistance. Proc Natl Acad Sci U S A 103,10741-10746. http://dx.doi.org/10.1073/pnas.0603509103.

Usechak P, Gates A, Webster CR. 2008. Activation of Focal Adhesion Kinase and JNK Contributes to the Extracellular Matrix and CAMP-GEF Mediated Survival From Bile Acid Induced Apoptosis in Rat Hepatocytes. J Hepatol 49,251261. http://dx.doi.org/10.1016/j.jhep.2008.04.015.

Wang L, Ma R, Flavell RA,Choi ME. 2002. Requirement of Mitogen-Activated Protein Kinase Kinase 3 (MKK3) for Activation of P38alpha and P38delta MAPK Isoforms by TGF-Beta 1 in Murine Mesangial Cells. J Biol Chem 277,47257-47262. http://dx.doi.org/10.1074/jbc.M208573200.

Webster CR, Srinivasulu U, Ananthanarayanan M, Suchy FJ and Anwer MS. 2002a. Protein Kinase B/Akt Mediates CAMP- and Cell Swelling-Stimulated Na+/Taurocholate Cotransport and Ntcp Translocation. J Biol Chem 277, 28578-28583. http://dx.doi.org/10.1074/jbc.M201937200. 
Webster CR, Usechak P, Anwer MS. 2002b. CAMP Inhibits Bile Acid-Induced Apoptosis by Blocking Caspase Activation and Cytochrome c Release. Am J Physiol Gastrointest Liver Physiol 283,G727-G738.

Webster CRL, Anwer MS. 1998. Cyclic AMP Mediated Protection Against Bile Acid Induced Apoptosis in Cultured Rat Hepatocytes. Hepatology 27,1324-1331. http://dx.doi.org/10.1002/hep.510270519.

Webster CRL, Anwer MS. 1999. Role of the PI3K/PKB Signaling Pathway in CAMP-Mediated Translocation of Rat Liver Ntcp. Am J Physiol 277,G1165-G1172.

Weston CR, Davis RJ. 2007. The JNK Signal Transduction Pathway. Curr Opin Cell Biol 19,142-149. http://dx.doi.org/10.1016/j.ceb.2007.02.001.

Wimmer R, Hohenester S, Pusl T, Denk GU, Rust C and Beuers U. 2008. Tauroursodeoxycholic Acid Exerts Anticholestatic Effects by a Cooperative CPKC Alpha-/PKA-Dependent Mechanism in Rat Liver. Gut 57,14481454. http://dx.doi.org/10.1136/gut.2007.140871.

Xu Z, Tavares-Sanchez OL, Li Q, Fernando J, Rodriguez CM, Studer EJ, Pandak WM, Hylemon PB, Gil G. 2007. Activation of Bile Acid Biosynthesis by the P38 Mitogen-Activated Protein Kinase (MAPK): Hepatocyte Nuclear Factor-4alpha Phosphorylation by the P38 MAPK Is Required for Cholesterol 7alpha-Hydroxylase Expression. J Biol Chem 282, 24607-24614. http://dx.doi.org/10.1074/jbc.M611481200.

Yoshida K. 2007. PKCdelta Signaling: Mechanisms of DNA Damage Response and Apoptosis. Cell Signal 19,892-901.

http://dx.doi.org/10.1016/j.cellsig.2007.01.027. 